\title{
Experimental chemical degradation compared to natural diagenetic alteration of collagen: implications for collagen quality indicators for stable isotope analysis
}

\author{
Michaela Harbeck • Gisela Grupe
}

Received: 22 August 2008 / Accepted: 5 February 2009/Published online: 4 March 2009

(C) Springer-Verlag 2009

\begin{abstract}
Stable isotopic ratios from archaeological bone collagen are valid palaeodietary indicators, but depend on sufficiently well preserved molecules and several collagen quality criteria have to be fulfilled (mostly collagen $\mathrm{wt} \%$, $\mathrm{C} \% ; \mathrm{N} \%, \mathrm{C} / \mathrm{N}$ molar ratio). For a reassessment of these quality criteria, and a better understanding of the chemical degradation of bone collagen, experimentally degraded modern bones and 54 archaeological human bones were investigated. In the course of the experimental degradation, alterations of isotopic ratios were paralleled by altered collagen quality criteria. The contrary was found in the case of the archaeological specimens. This implies that the commonly used collagen quality criteria may be insufficient and do not guarantee that stable isotopic values of the gelatine extracts will still represent the original biological signal.
\end{abstract}

Keywords Collagen degradation · Stable isotopes · $\mathrm{C} / \mathrm{N}$ ratio $\cdot$ Amino acid profile $\cdot$ Racemization

\section{Introduction}

The analysis of biomolecules such as collagen from archaeological bone finds provides multiple opportunities

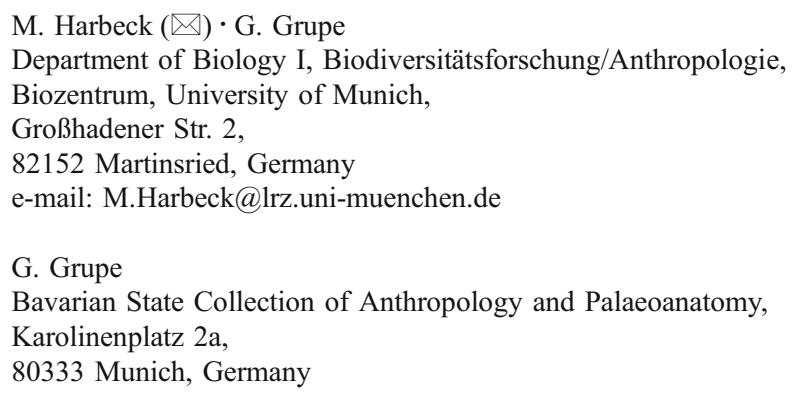

to get insights into the living conditions of vertebrates, including man. Type I collagen from bone material provides, among other things, the basis for reconstructing dietary patterns of ancient populations by measuring the ratios of stable carbon and nitrogen isotopes $\left(\delta^{13} \mathrm{C}, \delta{ }^{15} \mathrm{~N}\right.$; e.g. Ambrose 1993; Lee-Thorp et al. 1989). It should however be considered that degradation processes during the inhumation period can lead to structural alterations in the bone tissue or even a total loss of molecules (e.g. Collins et al. 2002; Hedges 2002). This is what renders biomolecular analyses difficult or even impossibly potentially producing diagenetic signals rather than original biological signals which could lead to wrong interpretations of the results. Consequently, great efforts have been made to characterize the state of collagen preservation to assure the retrieval of the original biological signal, and several publications on this topic are available (e.g. Ambrose 1990, 1993; Armstrong et al. 1983; DeNiro 1985; DeNiro and Weiner 1988; Koch et al. 2001; Tuross 2002; van Klinken 1999).

The ratio of stable isotopes in the collagen molecule is a function of its amino acid composition (Ambrose 1993; Grupe and Turban-Just 1998; Nelson et al. 1986). Accordingly, the integrity of collagen, especially its original amino acid composition (in the following referred to as "collagen quality"), is significantly important for the validity of the isotopic data.

The post mortem degradation of bone protein is mainly ascribed to the activity of microorganisms (Child 1995; Grupe 2001). In this process, the amino acid profile of collagen can be considerably altered, since microorganisms preferably tend to metabolize amino acids with a higher number of carbon atoms as a source of energy (Grupe and Turban-Just 1998; Grupe et al. 2000). It has been shown that the collagen of modern bone which had experimentally been inoculated with soil bacteria exhibits modified stable 
isotopic ratios for carbon and nitrogen after incubation (Balzer et al. 1997). The $\delta^{13} \mathrm{C}$-values shifted to more negative ratios, which is explained by the bacterial modification of the amino acid composition. The $\delta^{15} \mathrm{~N}$-values, however, exhibited a shift to more positive ratios in the magnitude of a whole trophic level effect, apparently a consequence of the cleavage of peptide bonds in the course of which the heavier ${ }^{15} \mathrm{~N}$ preferably remains in the substrate (Bada et al. 1989; Balzer et al. 1997; Grupe et al. 2000).

In environments protected from microbial attack, chemical degradation plays the major role in collagen deterioration. Here, the primary process is the hydrolysis of peptide bonds which leads to the formation of protein fragments that will be leached from the bone (Collins et al. 1995). Contrary to the hypotheses on the stability of mineralized collagen (Collins et al. 2002; Nielsen-Marsh et al. 2000), a considerable loss of collagen can also occur in relatively young samples (younger than 1,000 years; Smith et al. 2002, 2007). Furthermore, isotopic ratios are not only obscured by diagenetically modified amino acid profiles, but also by contaminations with exogenous organic substances (with the extraction protocol not always removable). This is why the quality of collagen as well as the purity of the collagen extraction products are both crucial for the authenticity of stable isotopic data.

In order to assess potential diagenetic alterations or contaminations of the collagen, several criteria (collagen quality criteria) are required and are usually applied. These criteria shall serve to identify samples which exhibit diagenetically altered isotopic signatures and thus yield no original biological information. The collagen quality criterion most commonly found in literature is the molar ratio of carbon $(\mathrm{C})$ to nitrogen $(\mathrm{N})(\mathrm{C} / \mathrm{N}$-molar). It is based upon an empirical study by DeNiro (1985) who defined a range of C/N-molar ratios from 2.9 to 3.6 as an indicator for good collagen preservation in archaeological bone, excluding contaminations (Hedges 2000; Ambrose 1990). According to a more recent study by van Klinken (1999) this range is set too broadly, he suggested a variation of $3.29+/-0.27$ only. Ambrose (1993) recommends as additional criteria the determination of the weight percentage of extractable collagen (collagen $\%$ ) from whole bone as well as the percent of carbon $(\mathrm{C} \%)$ and nitrogen $(\mathrm{N} \%)$ in the extract. $A$ minimal weight percentage of $1 \%$ collagen should be indicative of a good state of preservation, while van Klinken (1999) sets the respective threshold to $0.5 \mathrm{wt} \%$. According to Ambrose (1993), the weight percentages of C and $\mathrm{N}$ for unaltered collagen should exceed $3 \%$ for $\mathrm{C}$ and $1 \%$ for N. Higher values than those found in fresh collagen (43\% C and 16\% N, respectively) indicate contaminations (van Klinken 1999).

Another, however less frequently investigated indicator for collagen degradation, is the amino acid racemization, in particular aspartic acid (D/L-asp) has often been studied in this context (e.g. Bada et al. 1999; El Mansouri et al. 1996; Poinar et al. 1996; Tuross 2002). After death and in the course of the inhumation period, the D-form of this amino acid emerges from the L-form. That this racemization is a function of collagen degradation rather than of time and temperature only, as assumed previously, has been shown by Collins et al. (1999).

The aim of this study was to experimentally simulate the non-biogenic, chemical degradation processes of bone collagen and their possible effects on the $\delta^{13} \mathrm{C}$ and $\delta^{15} \mathrm{~N}$-isotopic values. Especially, the suitability of the quality criteria mentioned above was tested. Fresh human bone was degraded experimentally by heating in distilled water (cf. Roberts et al. 2002; Dobberstein et al. 2008), and examined with regard to the stable isotope ratios as well as the collagen quality criteria mentioned above, added by the establishment of amino acid profiles and the degree of aspartic acid racemization for the degraded and control samples. The same analyses were performed on archaeological bone material. The basis for the evaluation of diagenetically unchanged stable isotope ratios in the archaeological samples is given by the amino acid profile of the gelatine extract. Since the global isotopic ratio of the gelatine is composed of the mixture of single amino acid isotopic ratios, which in turn depends on the unchanged number of single amino acids in the molecule, significantly altered amino acid compositions will unavoidably result in altered isotopic compositions (see the following).

\section{Materials and methods}

\section{Experimental collagen degradation}

The modern human bone material was taken from the femur of one single adult male autopsy individual. A total of 15 cross-sections, each of $0.5 \mathrm{~cm}$ thickness, was taken from the diaphysis and cleaned manually. The bone marrow was scraped from the bone shaft, and no further bone processing like e.g. defatting was performed. Each cross-section was incubated in doubly distilled water at $90^{\circ} \mathrm{C}$ in sealed 250 $\mathrm{ml}$ glass bottles for $1 / 2,1,2,3,4,5,6,7,8,12,16,20,26$, 29 and 32 days.

Since it is not easy to get access to such material, and due to the limited amount of bone material available for the various analyses performed in our study, one piece was initially left untreated (control). After half a day of incubation, a gelatine was extractable from the sample which by all criteria available did not significantly differ from fresh bone collagen (see section Results), the "control" sample was instead used for the 32-day experiment. 


\section{Archaeological material}

The archaeological bone material consists of 54 human samples from different sites with inhumation times ranging from about 10,000 to 400 years. All samples had been excavated many years ago, and the archaeological documentation of the soil conditions is poor. Eleven bones come from Neolihic sites from south-east Anatolia (Gürcütepe site, ca. 7,500-7,000 BC; Nevalı Çori site, ca. 8,000-8,500 BC, Lösch et al. 2006), 20 human bones were taken from the northern German plain (Eider site, ca. 0 BC; Panker site, ca. 2,500 BC, Hirsch 2001; Hemmingstedt site, AD 1500, De Albuquerque-Leinenbach et al. 2000; and Flensburg site, AD 1300-1600, Gebhardt 2003), 15 human bones from southern Bavarian loess soils (Etting site, ca. AD 700, Czermak and Ledderose 2004), and finally nine bones from the western German Mosel-valley (Trier site, ca. AD 300400, Schröder et al. 1998).

\section{Collagen extraction}

All bones, whether fresh or archaeological, were processed in the same way. The samples were taken from the compact portion of the bone with a bandsaw, cleaned with distilled water in an ultrasonic bath (Bachofer) and air-dried. The specimens were homogenized with an oscillating mill (Retsch, type MM200). For the collagen extraction, $500 \mathrm{mg}$ of homogenized bone were demineralized in $10 \mathrm{ml}$ of $1 \mathrm{M} \mathrm{HCl}$ (Roth) for $20 \mathrm{~min}$ and then washed in distilled water by centrifuging at 3,000 rpm for $5 \mathrm{~min}$. The pellet was incubated in $10 \mathrm{ml}$ of $0.125 \mathrm{M} \mathrm{NaOH}$ (Sigma-Aldrich) for $20 \mathrm{~h}$ (to precipitate humic substances). After another washing step in distilled water, the samples were incubated in $10 \mathrm{ml}$ of $0.001 \mathrm{M} \mathrm{HCl}(\mathrm{pH} 3)$ for $10-17 \mathrm{~h}$ in a hot water bath (Memmert) at $90^{\circ} \mathrm{C}$ (for gelanization), filtered (pore size $5 \mu \mathrm{m}$ ) and lyophilized (according to Ambrose 1993). The amount of extracted gelatine in relation to the weight of the whole bone sample will be referred to as collagen weight proportion in percent (weight \%).

Amino acid analysis

For the establishment of amino acid profiles, there had to be an inevitable pre-selection, since it could only be applied to samples with a sufficient amount of extractable collagen. $2 \mathrm{mg}$ of the extracted gelatine were hydrolyzed with $1 \mathrm{ml} 6$ $\mathrm{M} \mathrm{HCl}$ for $11-15 \mathrm{~h}$ at $115^{\circ} \mathrm{C}$. After evaporation of the acid, the hydrolysate was solubilized in $0.2 \mathrm{M}$ lithium-citrate buffer (pH 2.2) and $20 \mu \mathrm{L}$ of this solution were forwarded to an amino acid analyser LKB Alpha Plus II (Pharmacia; detection limit $0.05 \mathrm{nmol} / \mu \mathrm{l})$.

Amino acid profiles of the samples were compared to numerous such profiles established on modern bones of varying mammal species as published in the literature and measured by our lab in the course of the previous years (e.g. Balzer et al. 1997; Grupe et al. 2000).

Aspartic acid racemization (D/L-asp)

For the measurement of the degree of aspartic acid racemization, the "collagen" was extracted (according to Ritz-Timme 1999) by preparation of the collagen-rich $\mathrm{HCl}$ insoluble fraction after cleaning and homogenization of the samples (see collagen extraction). Bone powder $(250 \mathrm{mg}$ ) was incubated at $4^{\circ} \mathrm{C}$ for $20 \mathrm{~h}$ in $5 \mathrm{ml} 1 \mathrm{M} \mathrm{HCl}$. After centrifugation, the collagen-rich pellet was washed in destilled water and finally lyophilized. The whole retrieved extract was then hydrolyzed for $6 \mathrm{~h}$ in $6 \mathrm{~N} \mathrm{HCl}$ at $100^{\circ} \mathrm{C}$. Acid and water were evacuated by vacuum, and the residue was then esterified with $1 \mathrm{ml}$ isopropanol and $100 \mu \mathrm{l}$ concentrated sulphuric acid for $1 \mathrm{~h}$ at $110^{\circ} \mathrm{C}$. Neutralization was achieved by addition of $1 \mathrm{ml} \mathrm{4N}$ ammoniac and $1 \mathrm{ml}$ dichloromethane. Next, the samples were acetylated with trifluoroacetic anhydride (TFA) for $15 \mathrm{~min}$ at $60^{\circ} \mathrm{C}$. The amino acids were now turned into TFA-isopropyl-esters and could be separated and quantified by gas chromatography (Schimadzu, Typ GC-9A). A chiral capillary column (Chiral-L-Val, Chrompak, $25 \mathrm{~m}, 0.25 \mathrm{~mm}$ inner diameter) was used with hydrogen as the carrier gas combined with a flame ionization detector.

Stable isotope analysis

$\delta^{15} \mathrm{~N}$ and $\delta^{13} \mathrm{C}$ in collagen were analysed by a coupled CHN-Analyzer (Thermo Finnigan NA2500)/Mass spectrometer (Thermo Finnigan Delta plus). About $0.3 \mathrm{mg}$ of the lyophylized sample were sealed in a Sn capsule and transferred to the $\mathrm{CHN}$-analyzer, where it was burnt under oxydizing conditions at $1,500^{\circ} \mathrm{C}$. The developing gas was transferred as $\mathrm{CO}_{2}$ and $\mathrm{N}_{2}$, respectively, with $\mathrm{He}$ (4.6) functioning as carrier gas via CONFLO II-Interface into the mass spectrometer. The isotopic ratios were measured against a calibrated, gaseous laboratory standard, whereby calibration was performed against the IAEA Standards NBS 19 and NBS 20 (for $\mathrm{CO}_{2}$ ), and against $\mathrm{N} 1$ and $\mathrm{N} 2$ (for $\mathrm{N}_{2}$ ). Isotopic ratios are expressed in relation to the PDB $\left(\delta^{13} \mathrm{C}\right)$ and $\operatorname{AIR}\left(\delta^{15} \mathrm{~N}\right)$ standards in the conventional $\delta$-notation. Measurement error does not exceed $0.15 \%$.

$\mathrm{N}$ - and $\mathrm{C}$ - weight percentages were determined from ratios of sample peak areas (in Vs) versus net sample weights. For calibration, both the elemental standards Atropine (C17H23NO3, 70.56\% C, 4.84\% N) and Cyclohexanone2.4-dinitrophenylhydrazone (C12H14N4O4, 51.79\% C, $20.14 \% \mathrm{~N}$, both ThermoQuest, Italia) were analyzed in each batch repeatedly ( $N=3$ for each standard). 
Statistical interpretation of the results

The evaluation of the state of preservation and hence the collagen quality was based on the quality criteria published previously by several authors. As seen from Table 1, these commonly used criteria are based on amino acid profiles, with amino acid abundances expressed in nmol\%. A specimen was labelled being of "poor collagen quality" when the analytical data were different from these criteria, whereby no further categories (badly preserved, very badly preserved etc.) were defined.

To detect possible relationships between the tested parameters, the correlation coefficient after Pearson was determined for metric datasets and after Spearman for ordinal datasets. In case of different levels of measurement the exact chi-squaretest after Fischer was used after transforming the data into nominal datasets to unravel associations. The calculations were performed with the SPSS software, version 1.30 . Only significant $(\alpha$-error $\leq 0.05)$ or highly significant $(\alpha$-error $\leq 0.01)$ results are reported.

\section{Results}

Experimentally degraded material

Changes of the collagen quality criteria $\mathrm{C} \%, \mathrm{~N} \%, \mathrm{C} / \mathrm{N}$-molar and weight percent of the extract, as well as changes in $\delta^{13} \mathrm{C}$ and $\delta^{15} \mathrm{~N}$-values with incubation time are shown in Fig. 1 and listed in Table 2. Only the collagen weight percent shows a highly significant correlation to the incubation time (rank correlation after Spearman, $r=0.773$ ). None of the other criteria shows a continuous in or decrease with incubation time. Drastic changes and clear deviations from the initial data of the control, however, become obvious between 8 and 12 days of incubation.

The amount of extractable gelatine (wt \%) decreases with increasing incubation time. The extraction of collagen for further analysis after day 12 was only successful from samples that had been incubated for 16 and 32 days, respectively. Correspondingly, there was no extract yield from samples incubated for 20,26 or 29 days.

In all samples up to and including the eighth day of incubation, the $\delta^{13} \mathrm{C}$-values oscillate around a mean value of $-20.34 \%$ with a very low standard deviation of $0.15 \%$ only. After a slight decrease of this value on the twelfth incubation day $(-22.63 \%)$, the $\delta$-values of the gelatine with an incubation time of 16 and 32 days $(-16.7$ and $-17.1 \%$, respectively) differ by more than $+3 \%$ (about $18 \%$ ) from the initial value and are hence considerably enriched with ${ }^{13} \mathrm{C}$.

The $\delta^{15} \mathrm{~N}$-values of the samples up to and including the eighth day of incubation are clustered around a mean value of $10.1 \%$. With $0.3 \%$, the standard deviation is slightly higher than for the $\delta^{13} \mathrm{C}$-values. Samples degraded artificially for 12 and 32 days become depleted in ${ }^{15} \mathrm{~N}$ by 4 and $2 \%$ respectively, while the sample which had been incubated for 16 days shows the initial value again.

Until the eighth incubation day, the molar $\mathrm{C} / \mathrm{N}$-ratio of the samples oscillates around a mean value of 3.7, with values ranging from 3.23 (eighth day of the experiment) to 4.17 (second incubation day), and a standard deviation of 0.23 . After a considerable decrease of the ratio after 12 incubation days down to 1.22 , it rises again until a ratio of 12 is reached on the 32 nd day.

The carbon and nitrogen weight-percentages of the extracted gelatine ( $\mathrm{C} \%$ and $\mathrm{N} \%)$ correspond to those of fresh bone with 44 and $14.9 \%$, respectively, until the eighth incubation day, with a standard deviation of 2.6 and $0.9 \%$. A considerable decrease of both weight percentages is evidenced from the twelfth incubation day onwards. On day 12 , only $6 \mathrm{wt} \%$ carbon, and $5.7 \mathrm{wt} \%$ nitrogen were recovered from the gelatine. For carbon, this corresponds to a loss of $86.4 \%$ from the original amount while only $61.8 \%$ of the initial weight percent of nitrogen are lost. For those samples incubated for 16 and 32 days, the differences in the decrease of $\mathrm{C} \%$ and $\mathrm{N} \%$ are smaller.

Table 1 Criteria for the state of preservation of collagen (according to DeNiro 1985; DeNiro and Weiner 1988; Elster et al. 1991; Grupe 1992; Masters 1987; Schoeninger et al. 1989; Taylor et al. 1989; Tuross et al. 1988)

Good collagen preservation

Poor collagen preservation

Approx. 1/3 of all amino acids are glycine (approx. $33 \mathrm{~mol} \%$ gly)

Approx. 1/3 of all amino acids consist of proline, hydroxyproline and alanine (approx. $33 \mathrm{~mol} \%$ )

Glycine/glutamic acid $=3-5$

Glycine/aspartic acid $>=5-7$

Hydroxyproline/aspartic acid $>=1,5$

Approx. $40 \mathrm{~mol} \%$ asparagine und serine

Glycine/glutamic acid $<2,5$

Glycine/aspartic acid $<5$

Hydroxyproline/aspartic acid $<1,5$

30-40 mol\% glutamic acid

$>250 \mathrm{nmol}$ amino acids/mg protein

$<50 \mathrm{nmol}$ aminoacids/mg protein

Aspartic acid/proline $<10$

Aspartic acid/proline $>10$ 
Fig. 1 Results of the temperature experiment. The $\mathrm{X}$-axis expresses the incubation time (in days) of the analyzed samples. On the Y-axis there are plotted the measured collagen criteria $(\mathrm{N} \%, \mathrm{C} \%$, $\mathrm{C} / \mathrm{N}$-molar, weight $\%$ ) and the stable isotope values of the elements $\mathrm{C}\left(\delta^{13} \mathrm{C}\right)$ and $\mathrm{N}\left(\delta^{15} \mathrm{~N}\right)$. Changes in the initial values can be noted from the 12th incubation day onwards. The samples between the 16th and 32nd incubation day did not yield any collagen any more

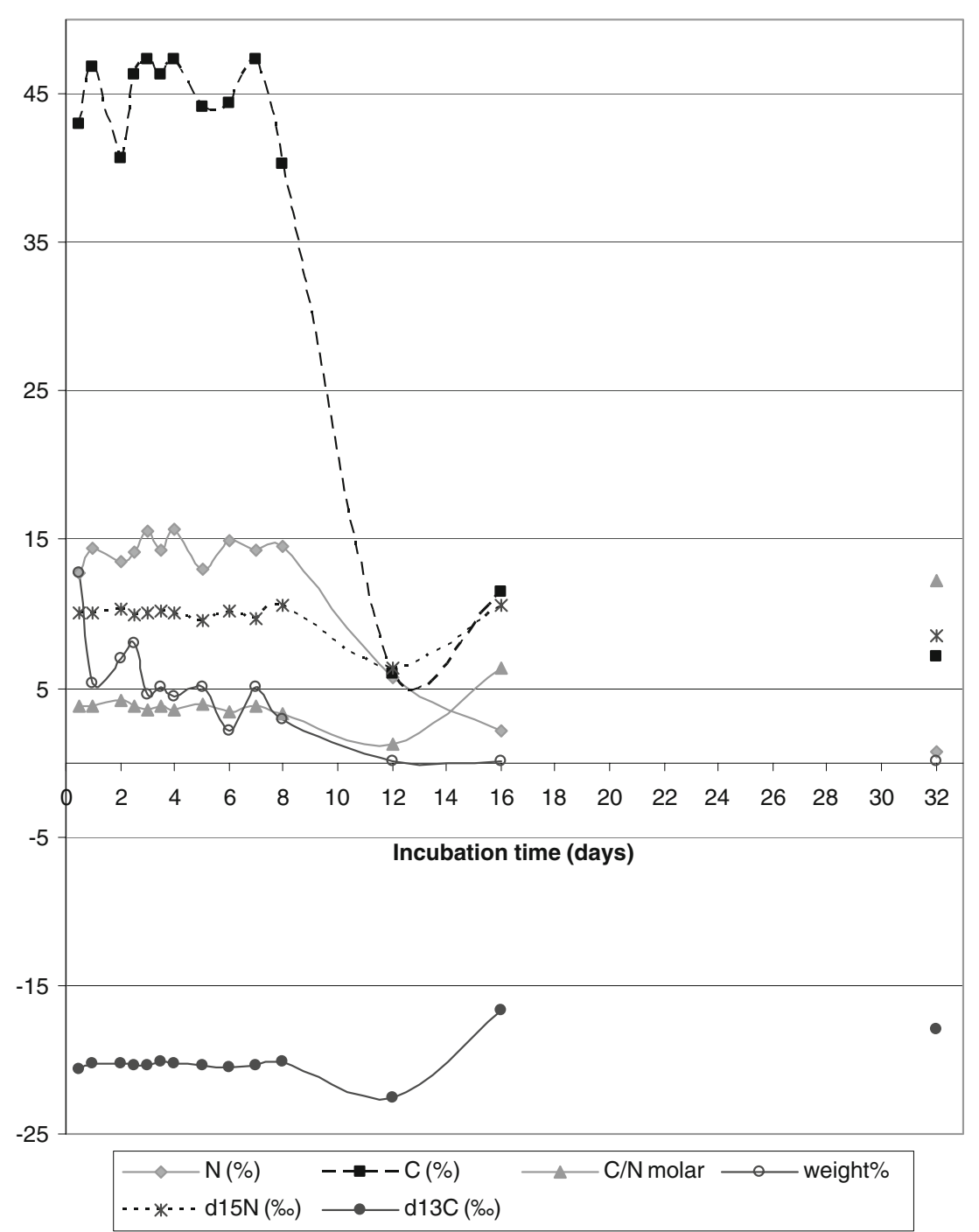

Amino acid profiles reflect the exact amino acid composition of the extract, which can directly be compared to the native composition of mammalian collagen. In addition, the technique applied by us detects breakdown products of physiological amino acids as well as bacterial ones. A "perfect" amino acid profile should therefore be superior to other quality criteria based e.g. on percentages of carbon and nitrogen.

With the exception of the sample from the second incubation day, the amino acid profiles are unaltered up to and including the eighth incubation day (Table 3). The amino acid profile of the 2 nd day specimen appears do be enriched with hydroxyproline and depleted with glycine. This is probably due to a preparation artifact (see section Discussion), since this altered amino acid profile had obviously no influence on the stable isotopic data of the extracted gelatine. While glycine is enriched with ${ }^{13} \mathrm{C}$ compared to the global collagen $\delta^{13} \mathrm{C}$ value, hydroxyproline is slightly depleted (Ambrose 1993), and therefore, an alteration of the global $\delta^{13} \mathrm{C}$-value would have been expected. It was not possible to establish amino acid profiles from the samples incubated for 12 and 32 days because less than the required $2 \mathrm{mg}$ extract was left. The amino acid profile of the sample incubated for 16 days, however, shows that at longer incubation times, the amino acid profile is altered und becomes non-collagenous, as e.g. depicted by a loss of one third of glycine (Table 3).

A steady increase of the aspartic acid racemization rate (D/L-asp) was detected with increasing incubation time (see Fig. 2; Table 2), and a highly significant correlation between $\mathrm{D} / \mathrm{L}$-asp and the duration of the experimental degradation exists (rank correlation after Spearman, $r=0.949$ ).

\section{Archaeological material}

Out of the 53 analyzed archaeological bone samples, gelatine could be retrieved from 45 specimens only. In 
Table 2 Stable isotope values, collagen weight percentages (wt $\%)$, percent of carbon $(\mathrm{C} \%)$ and nitrogen $(\mathrm{N} \%)$, $\mathrm{C} / \mathrm{N}$-molar and $\mathrm{D} / \mathrm{L}$-asp-values of the experimentally degraded bones

\begin{tabular}{llllllll}
\hline Incubation time (days) & $\delta^{15} \mathrm{~N}(\%)$ & $\delta^{13} \mathrm{C}(\%)$ & $\mathrm{Wt} \%$ & $\mathrm{~N}(\%)$ & $\mathrm{C}(\%)$ & $\mathrm{C} / \mathrm{N}$ molar & $\mathrm{D} / \mathrm{L}$-asp \\
\hline 0.5 & 10.03 & -20.63 & 12.73 & 12.78 & 43 & 3.79 & 0.0213 \\
1 & 10.05 & -20.29 & 5.29 & 14.36 & 46.76 & 3.8 & 0.041 \\
2 & 10.31 & -20.25 & 7.03 & 13.52 & 40.72 & 4.17 & 0.0605 \\
2.5 & 9.99 & -20.43 & 7.99 & 14.19 & 46.33 & 3.81 & 0.0737 \\
3 & 10.08 & -20.41 & 4.62 & 15.52 & 47.27 & 3.55 & 0.0768 \\
3.5 & 10.19 & -20.17 & 5.07 & 14.29 & 46.28 & 3.78 & 0.0846 \\
4 & 10.08 & -20.23 & 4.4 & 15.65 & 47.25 & 3.52 & 0.0876 \\
5 & 9.5 & -20.42 & 5.02 & 13.07 & 44.11 & 3.94 & 0.0943 \\
6 & 10.14 & -20.47 & 2.1 & 14.98 & 44.34 & 3.45 & 0.0909 \\
7 & 9.72 & -20.36 & 5.08 & 14.3 & 47.36 & 3.86 & 0.0618 \\
8 & 10.57 & -20.12 & 2.94 & 14.55 & 40.25 & 3.23 & 0.1183 \\
12 & 6.38 & -22.63 & 0.11 & 5.74 & 6.01 & 1.22 & 0.2314 \\
16 & 10.59 & -16.71 & 0.09 & 2.1 & 11.48 & 6.39 & 0.3579 \\
20 & & & & & & 0.4591 \\
26 & & & & & & & 0.5574 \\
29 & & & & & & & 0.57 \\
32 & 8.59 & -17.98 & 0.08 & 0.68 & 7.15 & 12.25 & 0.6028 \\
\hline
\end{tabular}

contrast to the experimentally degraded samples, it is impossible to reconstruct the initial, diagenetically unaffected measurement parameters (collagen $\mathrm{wt} \%, \mathrm{C} \%, \mathrm{~N} \%$ and $\mathrm{C} / \mathrm{N}$-molar). A sole presentation of the results thus is not reasonable; however, the relationships between the criteria examined are presented instead. Starting point here is the amino acid profile of the samples, because it can be considered that altered amino acid profiles will also lead to altered isotopic values (cf. also section Introduction). For comparative reasons, we plotted our results against the reference collagen amino acid composition published by Ambrose (1993), which matches amino acid profiles established on fresh mammalian bone collagen.

However, three samples from the Hemmingstedt site (Fig. 3) show the same specific amino acid profile as the sample experimentally degraded for 2 days. These samples are being taken out of the comparative analysis because it is not for sure whether this specific amino acid profile is due to special diagenetic effects, or rather a preparation/ measurement artifact (see section Super collagen ).

Table 3 Amino acid profiles of the experimentally degraded samples (in nmol\%)

\begin{tabular}{|c|c|c|c|c|c|c|c|c|c|c|c|c|c|c|c|c|c|c|c|}
\hline Incubation time (in days) & OH-Pro & asp & thr & ser & glu & pro & gly & ala & cys & val & met & ile & leu & tyr & phe & his & $\mathrm{OH}$-lys & lys & arg \\
\hline 0.5 & 11 & 4.4 & 2.8 & 4.3 & 8.4 & 9.4 & 32 & 13 & 0.1 & 1.3 & 1 & 0.5 & 4 & 0.2 & 1.3 & 0.3 & 0 & 0.5 & 3.4 \\
\hline 1 & 10 & 8 & 3.1 & 4.7 & 6.9 & 9.6 & 29.1 & 12.1 & 0 & 0 & 0.2 & 1.3 & 4.1 & 0.8 & 0.7 & 0.4 & 0.5 & 0.1 & 2.4 \\
\hline 2 & 16.3 & 6.9 & 3.5 & 4.3 & 7 & 10.4 & 29.6 & 11.2 & 0 & 0 & 0.3 & 1.1 & 4.4 & 0.6 & 0.7 & 0.3 & 0.6 & 0 & 2.5 \\
\hline 2.5 & 11.6 & 6.6 & 2.3 & 3.5 & 7.1 & 12.7 & 32.6 & 9.8 & 0.05 & 1.2 & 0.3 & 1 & 4 & 2.7 & 0.6 & 0.2 & 0 & 0.3 & 3.5 \\
\hline 3 & 9 & 3.3 & 1.5 & 4.6 & 8.2 & 13.5 & 31.6 & 13.9 & 0.07 & 1 & 0.3 & 1.2 & 3.9 & 0 & 2.4 & 1 & 0 & 0.6 & 4 \\
\hline 3.5 & 10.7 & 3.5 & 3.2 & 4 & 8 & 9.1 & 32.4 & 15.4 & 0.1 & 1.6 & 1.1 & 0.6 & 4.2 & 0.2 & 1.3 & 0.5 & 0 & 0.7 & 3.7 \\
\hline 4 & 9.8 & 5.5 & 3.1 & 5 & 7.4 & 12.7 & 35.1 & 12.2 & 0.06 & 1.3 & 0.3 & 1 & 4 & 0 & 0.8 & 0.5 & 0.6 & 0.3 & 0 \\
\hline 5 & 10.8 & 3.9 & 2.5 & \begin{tabular}{|l|} 
\\
\end{tabular} & 7.4 & 12.4 & 29.2 & 13.7 & 0 & 0.8 & \begin{tabular}{|l} 
\\
\end{tabular} & 1 & 3.6 & 0 & 5.7 & 0.7 & 0 & 0.2 & 3.7 \\
\hline 6 & 10.5 & 6.2 & 2.8 & 3 & 7 & 12.9 & 33.1 & 9.5 & 0.07 & 1.6 & 0.2 & 1.6 & 4.5 & 1.9 & 0.7 & 0.3 & 0 & 0.4 & 3.9 \\
\hline 7 & 11.1 & 6.8 & 2.3 & \begin{tabular}{|l}
3.5 \\
\end{tabular} & 7.1 & 12.6 & 32.3 & 10 & 0.06 & 1.2 & 0.4 & 1.1 & 4 & 3.1 & 0.6 & 0.2 & 0 & & 3.5 \\
\hline 8 & 10.3 & 4.8 & 3 & \begin{tabular}{|l}
4.9 \\
\end{tabular} & 7.5 & 12.7 & 32.4 & 11.9 & 0.1 & 1.6 & 0 & 1.3 & 3.7 & 0.9 & 0.4 & 0.3 & 0 & 0.1 & 7.9 \\
\hline \multicolumn{20}{|l|}{12} \\
\hline 16 & 13.3 & 3.5 & $10^{\mathrm{a}}$ & 4.2 & $5.5^{\mathrm{a}}$ & 11.2 & $26.5^{\mathrm{a}}$ & 12.5 & $0.6^{\mathrm{a}}$ & $2^{a}$ & $2.8^{\mathrm{a}}$ & $1.9^{\mathrm{a}}$ & $2.9^{\mathrm{a}}$ & 0 & $0^{\mathrm{a}}$ & $2.8^{\mathrm{a}}$ & 0 & 0 & 3.8 \\
\hline Mean & 10.5 & 5.3 & 2.7 & 4.2 & 7.5 & 11.8 & 31.9 & 12.15 & 0.06 & 1.15 & 0.39 & 1 & 4 & 1 & 1.45 & 0.46 & 0.1 & 0.4 & 3.6 \\
\hline Range & $10-16.3$ & 3.3-8 & $1.5-3.5$ & 3-5 & 6.9-8.4 & $9.1-13.5$ & 29-35.1 & 9.5-15.4 & 0-0.1 & 0-1.6 & $0-1.1$ & $0.5-1.3$ & 3.6-4.5 & $0-3.1$ & $0.4-2.4$ & $0.2-0.7$ & $0-0.6$ & $0-0.4$ & $0-7.9$ \\
\hline Deviation & 2.8 & -1.8 & $7.3^{\mathrm{a}}$ & 0.04 & -2 & -0.56 & $-5.48^{\mathrm{a}}$ & 0.35 & 0.54 & 0.85 & 2.36 & 0.9 & -1.1 & -1 & -1.45 & 2.34 & -0.1 & -0.4 & 0.2 \\
\hline
\end{tabular}

The mean and the range comprises the samples with unaltered isotopic values ( 0.5 to 8 days incubated, with the exception of the sample incubated for 2 days). Deviation = difference between the values of the sample incubated for 16 days and the mean

${ }^{\text {a }}$ Samples of this specimen with values outside the range (of the samples 0.5 up to 8 ) and deviations exceeding $5 \mathrm{nmol} \%$ 


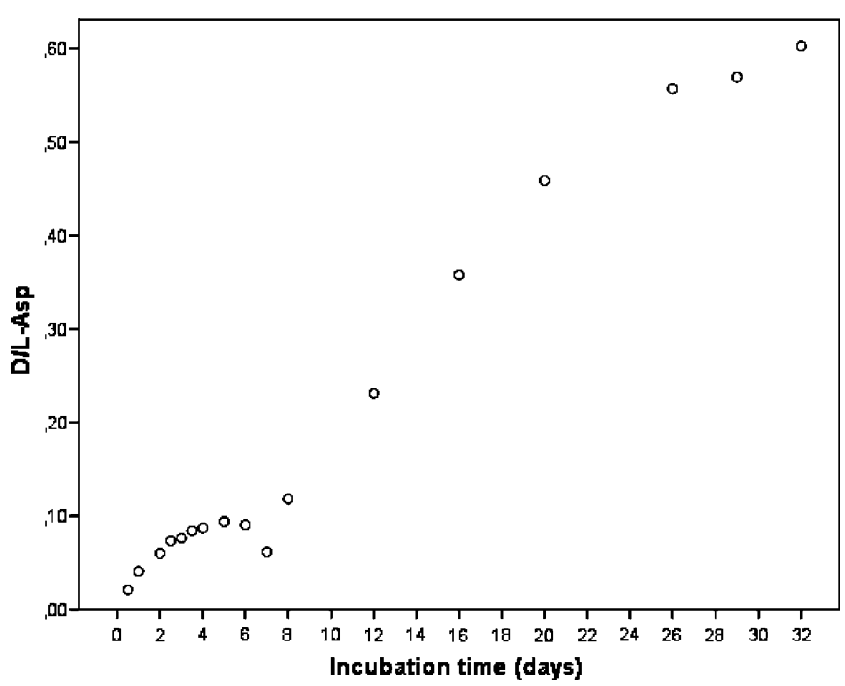

Fig. 2 Racemization rate of aspartic acid (D/L-Asp) of the experimentally degraded bones

A comparison of the amino acid profiles of the other archaeological samples with the collagen yield shows that a preferred loss of certain amino acids (Fig. 4) does occur. Preferably, either amino acids that make up only a small proportion of the collagen (e.g. cysteine) are lost, or amino acids with a high number of carbon atoms (e.g. tyrosine). Microbial amino acids were not detected in any of the archaeological samples, due to the gelatine extraction procedure. Among the 45 analyzable samples, 24 showed an amino acid profile that meets the collagen quality criteria (cf. Table 1; in the following referred to as samples with good collagen quality). All amino acid profiles obtained from the archaeological specimens are listed in Table 4, while the collagen quality criteria are listed in Table 5.

Contrary to our expectations, not a single one of the quality criteria tested (collagen $\mathrm{wt} \%, \mathrm{C} \%, \mathrm{~N} \%, \mathrm{C} / \mathrm{N}$ molar,
D/L-asp, Table 5) can be closely associated with collagen quality as defined by the amino acid profile in a statistically significant way. Samples with poor collagen quality show carbon percentages between $26.84 \%$ and $59.20 \%$ (mean: $43.04 \%$ ), while samples with good collagen quality have values from $13.4 \%$ to $54.6 \%$ (mean: $41.77 \%$ ). The nitrogen percentages of the archaeological samples range from 3.3 to $21.1 \%$. Here, as well samples with good (mean: $13.62 \%$ ) and poor collagen quality (mean: 12.84\%) show values scattered over the whole observed range. Looking at the collagen content in wt\% (classified in grades, Fig. 5) in relation to the amino acid profile, a tendency is depicted in as much as samples with weight percentages below 5\% gelatine are more often prone to show altered amino acid profiles (Fig. 5).

For the assessment of a correlation between collagen quality and the $\mathrm{C} / \mathrm{N}$-molar ratio, the samples were classified in two categories. The one category comprises all samples with a $\mathrm{C} / \mathrm{N}$ ratio of 2.9-3.6 (range for well-preserved collagen according to DeNiro 1985), while the other category represents those samples with a ratio above 3.6 (values below 2.9 were not detected in any of our samples). Figure 6 shows that samples with a $\mathrm{C} / \mathrm{N}$ ratio between 2.9 and 3.6 consist of specimens with unaltered as well as with altered amino acid profiles. Even when considering the narrower range of suitable $\mathrm{C} / \mathrm{N}$ molar values as defined by van Klinken (1999), namely from 3.02 to 3.56 , the result remains the same.

The $\mathrm{D} / \mathrm{L}$-asp-value shows a tendency to be higher in samples with altered amino acid profiles (Fig. 7). Samples with poor collagen quality show $\mathrm{D} / \mathrm{L}$-values between 0.036 and 0.0686 (mean: 0.048), while samples with good collagen quality have values from 0.0248 to 0.0455 (mean: 0.0344 ). Only a small overlap in the $\mathrm{D} / \mathrm{L}$-asp-value of 0.0095 is evidenced between the samples of good and poor collagen. We found highly significant negative correlations between the weight percentages of collagen and the $\mathrm{D} / \mathrm{L}$ -
Fig. 3 Amino acid profile of the samples from the Hemmingstedt site (dots) and of fresh collagen (according to Ambrose 1993) (bars)

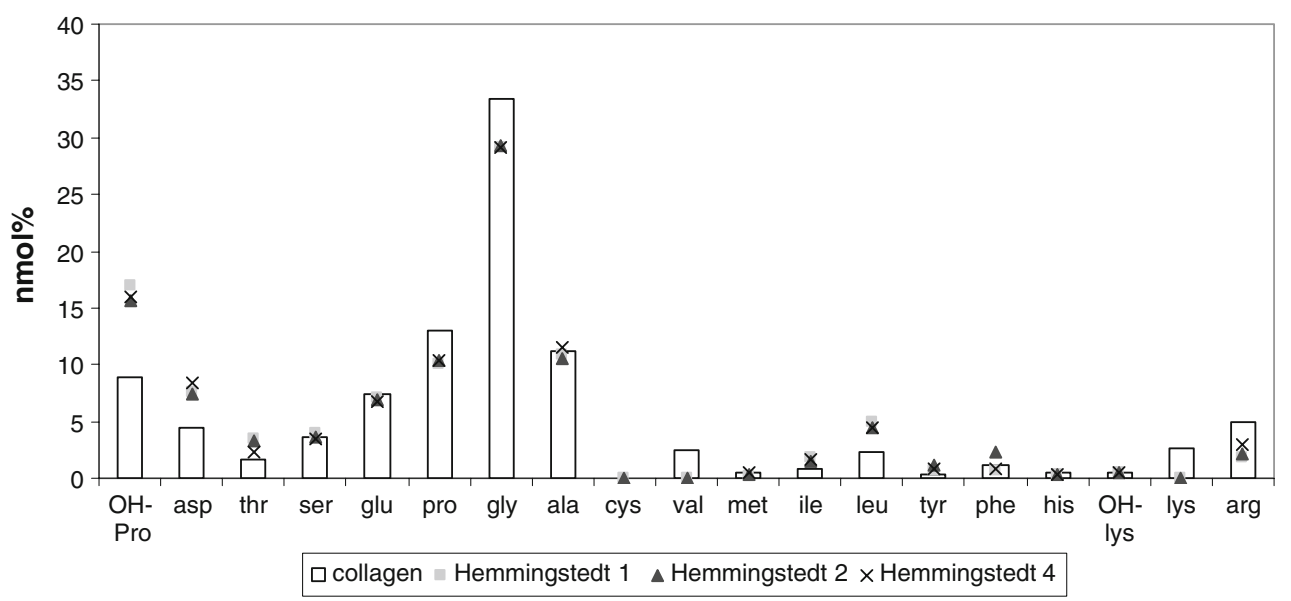


Fig. 4 Drop-out rates of single amino acids, expressed in the number of samples in which the amino acid could not be detected (dots) and nmol\%-proportion of the single amino acids in native collagen (according to Ambrose 1993) (bars)

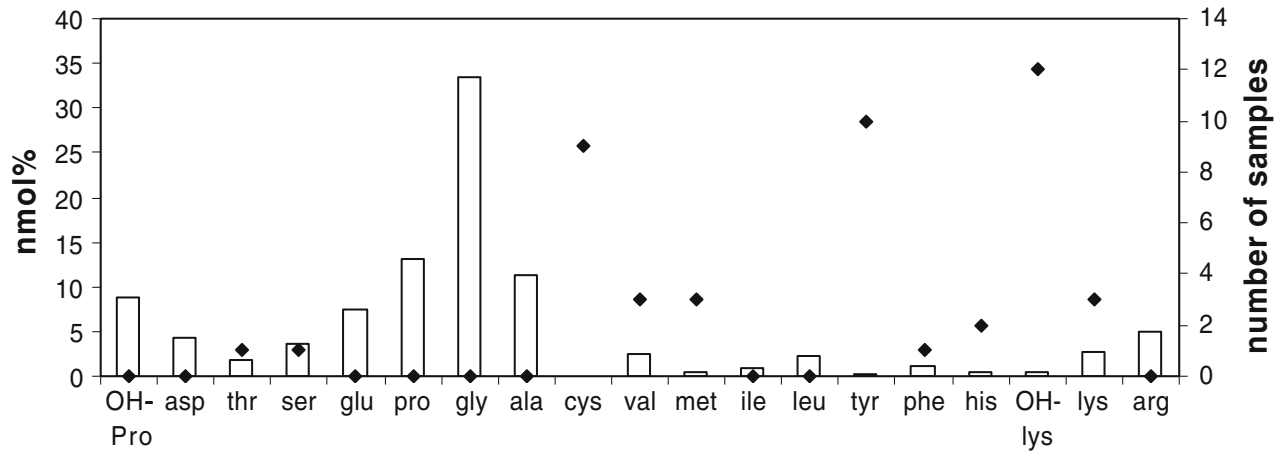

asp value, but the correlation coefficient after Pearson is very weak $(-0.374)$. A correlation between the $\mathrm{C} \%$ - and $\mathrm{N}$ $\%$-values and the collagen weight percentages (correlation coefficient after Pearson: 0.553 and 0.459 ) as well as the D/ L-asp value $(-0.3$ and -0.34$)$ also exists.

\section{Discussion}

Experimentally induced diagenetic modification of collagen

The survey of the collagen weight percentages of the samples with different incubation times showed that the collagen content of the bone sample decreases with proceeding experimentally generated degradation. Since the samples had been kept in distilled water, their degradation is due to the hydrolysis of collagen, fragmentation of the molecule, formation of water-soluble peptides and free amino acids which are leached from the bone. The observed small deviations from a continuous decrease can be explained by slight variations in bone size and density of the individual samples. The D/L-asp-value increases both with incubation time and collagen loss. This is explained by the fact that the racemization of collagen is mainly driven by degradation of the triple helix, whose intact structure prevents racemizaton (van Duin and Collins 1998). As collagen is fragmented in the course of the incubation time and the triple helix denatures, D-asp will accumulate at the free ends of the helix (Collins et al. 1995). Furthermore, the extracted insoluble fraction (by acid-extraction, see Materials and methods) is not composed solely of collagen, some non-collagenous proteins (NCPs) are always co-extracted. These and the nonhelical regions of the collagen molecule can undergo racemization independently from the collagen molecule itself.

By contrast, the amino acid composition, the $\mathrm{C} \%, \mathrm{~N} \%$ and $\mathrm{C} / \mathrm{N}$-molar criteria show abrupt changes of their original values after the eight incubation day. At lower incubation times, carbon and nitrogen weight proportions exhibited values in agreement with those of fresh collagen (mean value of 44 and $14.9 \%$ respectively). $\mathrm{C} / \mathrm{N}$-molar ratios varied around 3.4-4.2, thereby exceeding the suggested ratios for collagen which has already been altered to a certain extent, but still kept its original stable isotopic signal (DeNiro 1985; van Klinken 1999). With the exception of sample 2 (see Super collagen), the amino acid composition shows only slight variations until day 8 , changes of the amino acid composition could only be detected in sample 16. The sample of the 12th incubation day shows a clear decrease of $\mathrm{C} \%$ and a relatively smaller decrease of $\mathrm{N} \%$. This indicates a preferential loss of carbon from the sample and explains the decreased $\mathrm{C} / \mathrm{N}$-molarvalue. Possibly, amino acids with high $\mathrm{C} / \mathrm{N}$-proportions may be lost initially, or position effects within certain amino acids may be responsible for this observation. Unfortunately, the amino acid composition of this sample could not be established, so this explanation remains hypothetical.

The loss of selective amino acids becomes evident in the specimen which had been incubated for 16 days, and while only $\mathrm{N} \%$ is further diminished, the $\mathrm{C} / \mathrm{N}$-molar ratio consequently increases. A more positive $\mathrm{C} / \mathrm{N}$-ratio can be achieved either by an increase in carbon in relation to nitrogen, or by a relative decrease in nitrogen, respectively. Single amino acids have very different molar $\mathrm{C} / \mathrm{N}$-ratios such as 9 in phenylalanine and tyrosine, 6 in leucine, but only 2 in glycine and histidine. If the bone collagen preferably loses the very hydrophilic, and due to its size, readily soluble glycine by chemical hydrolysis as is evidenced by Table 2, an altogether higher $\mathrm{C} / \mathrm{N}$-ratio and a less diminished carbon percentage in relation to nitrogen would explain the result.

Experimental degradation through abiotic collagen hydrolysis was accompanied by changes in the stable isotope ratios. While the $\delta^{15} \mathrm{~N}$-values of the residual, unhydrolized molecule become finally depleted with ${ }^{15} \mathrm{~N}$ (decrease of the original $\delta$-value by more then $2 \%$ ), $\delta^{13} \mathrm{C}$-values clearly increase with proceeding degradation (becoming enriched with ${ }^{13} \mathrm{C}$ by more than $3 \%$ ). Such alterations of $\delta$-values would be significant in the case of dietary or habitat reconstruction, since a decrease of $\delta^{15} \mathrm{~N}$ by $2 \%$ closely corresponds to one trophic level (Ambrose 1993), and an 
Table 4 Amino acid profiles of the archeological bones (in nmol\%)

\begin{tabular}{|c|c|c|c|c|c|c|c|c|c|c|c|c|c|c|c|c|c|c|c|}
\hline sample & OH-Pro & asp & thr & ser & glu & Pro & gly & Ala & cys & Val & met & ile & Leu & Tyr & phe & His & OH-lys & Lys & arg \\
\hline Gü2 ${ }^{a}$ & $10.1^{a}$ & $3.5^{\mathrm{a}}$ & $3.8^{\mathrm{a}}$ & $3.5^{\mathrm{a}}$ & $8^{a}$ & $9.3^{a}$ & $32^{a}$ & $14^{\mathrm{a}}$ & $0.1^{\mathrm{a}}$ & $1.7^{\mathrm{a}}$ & $0.5^{\mathrm{a}}$ & $0.7^{a}$ & $4.1^{\mathrm{a}}$ & $0.2^{\mathrm{a}}$ & $1.5^{\mathrm{a}}$ & $0.6^{\mathrm{a}}$ & $0.5^{\mathrm{a}}$ & $0.1^{\mathrm{a}}$ & $3.9^{\mathrm{a}}$ \\
\hline Gü3 ${ }^{a}$ & $0.7^{\mathrm{a}}$ & $3.2^{\mathrm{a}}$ & $3.4^{a}$ & $3.7^{\mathrm{a}}$ & $8.1^{\mathrm{a}}$ & $9.5^{\mathrm{a}}$ & $32.9^{\mathrm{a}}$ & $14^{\mathrm{a}}$ & $0.1^{\mathrm{a}}$ & $1.5^{\mathrm{a}}$ & $0.5^{\mathrm{a}}$ & $0.6^{a}$ & $4.2^{\mathrm{a}}$ & $0.2^{\mathrm{a}}$ & $1^{a}$ & $0.4^{\mathrm{a}}$ & $0.7^{a}$ & $0.5^{\mathrm{a}}$ & $3.5^{a}$ \\
\hline NC12 & 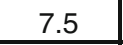 & 2 & 1 & 1 & 3.3 & 13.5 & 34.2 & 22.3 & 0 & 2.4 & 0.2 & 0.9 & 2.8 & 0.1 & 0.8 & 0.2 & 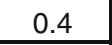 & 3.5 & 3.9 \\
\hline NC16 & $\leq$ & 2.1 & 1.2 & 1 & 3.2 & 14 & 34 & 22.1 & 0 & 2.6 & 0.2 & 0.9 & 2.9 & 0.1 & 1.1 & 0.1 & .0. & 3.5 & 3.4 \\
\hline $\mathrm{NC} 17$ & 9 & 0.6 & 0 & 0 & 2.3 & 20 & 44 & 9.7 & 0 & 1.9 & 0 & 0.4 & 1 & 0.2 & 0 & 0 & 1 & 1.2 & 10.9 \\
\hline NC18 & 10.7 & 3.9 & 2 & 2 & 5.6 & 17 & 23.8 & 14.4 & 17 & 2.9 & 0.6 & 1.2 & 3.7 & 0.1 & 1.7 & 0.2 & 3 & 3.5 & 6.1 \\
\hline $\mathrm{P} 1^{\mathrm{a}}$ & $10.2^{a}$ & $5.7^{\mathrm{a}}$ & $2.8^{\mathrm{a}}$ & $3.2^{\mathrm{a}}$ & $6.4^{\mathrm{a}}$ & $12.6^{\mathrm{a}}$ & $32.7^{\mathrm{a}}$ & $10^{\mathrm{a}}$ & $0.1^{\mathrm{a}}$ & $1.3^{\mathrm{a}}$ & $0.4^{\mathrm{a}}$ & $1.2^{\mathrm{a}}$ & $3.5^{\mathrm{a}}$ & $5.4^{\mathrm{a}}$ & $0.4^{\mathrm{a}}$ & $0.3^{\mathrm{a}}$ & $0.4^{\mathrm{a}}$ & $0.1^{\mathrm{a}}$ & $3.4^{\mathrm{a}}$ \\
\hline $\mathrm{P}^{\mathrm{a}}$ & $8^{a}$ & $5.3^{\mathrm{a}}$ & $2.4^{\mathrm{a}}$ & $2.3^{\mathrm{a}}$ & $5.7^{\mathrm{a}}$ & $13.2^{\mathrm{a}}$ & $34.6^{\mathrm{a}}$ & $9.1^{\mathrm{a}}$ & $0.1^{\mathrm{a}}$ & $1.4^{\mathrm{a}}$ & $0.5^{\mathrm{a}}$ & $1^{a}$ & $3.5^{\mathrm{a}}$ & $7.6^{\mathrm{a}}$ & $0.4^{\mathrm{a}}$ & $0.4^{\mathrm{a}}$ & $0^{\mathrm{a}}$ & $0.2^{\mathrm{a}}$ & $3.6^{\mathrm{a}}$ \\
\hline $\mathrm{P}^{\mathrm{a}}$ & $3^{a}$ & $4.9^{\mathrm{a}}$ & $0.7^{\mathrm{a}}$ & $1.9^{\mathrm{a}}$ & $6.7^{\mathrm{a}}$ & $13.9^{\mathrm{a}}$ & $35.7^{\mathrm{a}}$ & $9.9^{a}$ & $0.1^{\mathrm{a}}$ & $1.6^{\mathrm{a}}$ & $0.5^{\mathrm{a}}$ & $1.3^{\mathrm{a}}$ & $3.6^{\mathrm{a}}$ & $4.5^{\mathrm{a}}$ & $0.7^{\mathrm{a}}$ & $0.6^{\mathrm{a}}$ & $0^{a}$ & $0.3^{\mathrm{a}}$ & $3.6^{\mathrm{a}}$ \\
\hline $\mathrm{P}^{\mathrm{a}}$ & 7 & $4.5^{\mathrm{a}}$ & $2.4^{\mathrm{a}}$ & $3.9^{\mathrm{a}}$ & $7.4^{\mathrm{a}}$ & $13^{a}$ & $31^{a}$ & $13.3^{\mathrm{a}}$ & $0.1^{\mathrm{a}}$ & $1.2^{\mathrm{a}}$ & $0.2^{\mathrm{a}}$ & $1.7^{\mathrm{a}}$ & $3.4^{\mathrm{a}}$ & $0.2^{\mathrm{a}}$ & $4.4^{\mathrm{a}}$ & $1.4^{\mathrm{a}}$ & $0^{a}$ & $0.3^{\mathrm{a}}$ & $0.5^{a}$ \\
\hline ES & 11.8 & 3.6 & 2.9 & 4.5 & 6 & 8.3 & 32.9 & 20 & 0.1 & 1.4 & 0.7 & 0.6 & 4.1 & 0.1 & 1.4 & 0.4 & 0.6 & 0.1 & 2.5 \\
\hline T1 & 1.7 & 3.4 & 3.2 & 5.8 & 8.2 & 13.8 & 30 & 13.5 & 0.1 & 1 & 0.2 & 1 & 3.3 & 0 & 2.9 & 0.6 & 0.3 & 0.2 & 0.7 \\
\hline$T 2^{\mathrm{a}}$ & $11^{\mathrm{a}}$ & $3.5^{\mathrm{a}}$ & $1.9^{\mathrm{a}}$ & $3.7^{\mathrm{a}}$ & $7.2^{\mathrm{a}}$ & $13^{a}$ & $31.2^{\mathrm{a}}$ & $12.6^{\mathrm{a}}$ & $0.1^{\mathrm{a}}$ & $0.8^{a}$ & $0.2^{\mathrm{a}}$ & $1.3^{\mathrm{a}}$ & $3.2^{\mathrm{a}}$ & $0.3^{\mathrm{a}}$ & $5.9^{\mathrm{a}}$ & $1.9^{\mathrm{a}}$ & $0^{a}$ & $0.6^{\mathrm{a}}$ & $1.2^{\mathrm{a}}$ \\
\hline$T 3^{a}$ & $9^{a}$ & $5.9^{\mathrm{a}}$ & $2.5^{\mathrm{a}}$ & $5.1^{\mathrm{a}}$ & $8^{a}$ & $12.4^{\mathrm{a}}$ & $33.2^{\mathrm{a}}$ & $13^{\mathrm{a}}$ & $0.1^{\mathrm{a}}$ & $1.8^{\mathrm{a}}$ & $0.3^{\mathrm{a}}$ & $1.6^{\mathrm{a}}$ & $4.8^{\mathrm{a}}$ & $0^{a}$ & $0.7^{\mathrm{a}}$ & $0.3^{\mathrm{a}}$ & $0.7^{\mathrm{a}}$ & $0.1^{\mathrm{a}}$ & $2.4^{\mathrm{a}}$ \\
\hline$T 4^{a}$ & & $4^{a}$ & $2.9^{\mathrm{a}}$ & $4.9^{\mathrm{a}}$ & $7.2^{\mathrm{a}}$ & $12.9^{\mathrm{a}}$ & $28.8^{\mathrm{a}}$ & $13.2^{\mathrm{a}}$ & $0.2^{\mathrm{a}}$ & $1.3^{\mathrm{a}}$ & $1.2^{\mathrm{a}}$ & $2.1^{\mathrm{a}}$ & $5^{a}$ & $0^{a}$ & $3.5^{\mathrm{a}}$ & $0.8^{\mathrm{a}}$ & & $0.3^{\mathrm{a}}$ & $0.4^{a}$ \\
\hline$T 5^{a}$ & $9^{a}$ & $4.2^{\mathrm{a}}$ & $2.4^{\mathrm{a}}$ & $3.7^{\mathrm{a}}$ & $6.8^{\mathrm{a}}$ & $12.7^{\mathrm{a}}$ & $19.3^{\mathrm{a}}$ & $12.3^{\mathrm{a}}$ & $0.1^{\mathrm{a}}$ & $1^{a}$ & $0.3^{\mathrm{a}}$ & $1.6^{\mathrm{a}}$ & $3.2^{\mathrm{a}}$ & $0.3^{\mathrm{a}}$ & $5^{a}$ & $2.1^{\mathrm{a}}$ & $0^{a}$ & $0.8^{\mathrm{a}}$ & $4.5^{a}$ \\
\hline$T 6^{a}$ & $8.7^{\mathrm{a}}$ & $1.9^{\mathrm{a}}$ & $1.4^{\mathrm{a}}$ & $6.2^{\mathrm{a}}$ & $7.2^{\mathrm{a}}$ & $14.2^{\mathrm{a}}$ & $31.2^{\mathrm{a}}$ & $14^{\mathrm{a}}$ & $0.2^{\mathrm{a}}$ & $1.1^{\mathrm{a}}$ & $0.4^{\mathrm{a}}$ & $1.6^{\mathrm{a}}$ & $3.4^{\mathrm{a}}$ & $0^{a}$ & $4^{a}$ & $1.5^{\mathrm{a}}$ & $0^{a}$ & $0.3^{\mathrm{a}}$ & $2.6^{a}$ \\
\hline $\mathrm{T}^{\mathrm{a}}$ & $9.9^{\mathrm{a}}$ & $5.5^{\mathrm{a}}$ & $3.3^{\mathrm{a}}$ & $5.9^{\mathrm{a}}$ & $7.6^{\mathrm{a}}$ & $11.2^{\mathrm{a}}$ & $30.6^{\mathrm{a}}$ & $11.7^{\mathrm{a}}$ & $0.1^{\mathrm{a}}$ & $1.5^{\mathrm{a}}$ & $0.3^{\mathrm{a}}$ & $1.9^{\mathrm{a}}$ & $4.1^{\mathrm{a}}$ & $0.9^{\mathrm{a}}$ & $0.6^{\mathrm{a}}$ & $0.3^{\mathrm{a}}$ & $0.8^{a}$ & $0^{a}$ & $4^{a}$ \\
\hline$T 8^{\mathrm{a}}$ & a & $5.2^{\mathrm{a}}$ & $2.9^{\mathrm{a}}$ & $4.4^{\mathrm{a}}$ & $7.5^{\mathrm{a}}$ & $12.7^{\mathrm{a}}$ & $31.2^{\mathrm{a}}$ & $14.5^{\mathrm{a}}$ & $0.1^{\mathrm{a}}$ & $1.611^{\mathrm{a}}$ & $0^{\mathrm{a}}$ & $1.9^{\mathrm{a}}$ & $4.4^{\mathrm{a}}$ & $0^{\mathrm{a}}$ & $0.6^{\mathrm{a}}$ & $0.6^{\mathrm{a}}$ & $0.6^{\mathrm{a}}$ & $0.1^{\mathrm{a}}$ & $2.7^{\mathrm{a}}$ \\
\hline $\mathrm{Tg}^{\mathrm{a}}$ & $a^{a}$ & $4.3^{\mathrm{a}}$ & $2.4^{\mathrm{a}}$ & $4.2^{\mathrm{a}}$ & $7.3^{\mathrm{a}}$ & $12.9^{\mathrm{a}}$ & $30.6^{\mathrm{a}}$ & $12.9^{\mathrm{a}}$ & $0.1^{\mathrm{a}}$ & $1.2^{\mathrm{a}}$ & $0.2^{\mathrm{a}}$ & $1.7^{\mathrm{a}}$ & $3.3^{\mathrm{a}}$ & $0.3^{\mathrm{a}}$ & $5^{a}$ & $1.8^{\mathrm{a}}$ & 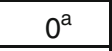 & $0.5^{\mathrm{a}}$ & $0.6^{a}$ \\
\hline $\mathrm{E} 1$ & 7. & 2.7 & 1.6 & 1.4 & 3.9 & 13 & 31.5 & 19.9 & 0.1 & 2.3 & 0 & 0.8 & 2.6 & & 1.3 & 0.4 & 0.2 & 3.8 & 6.9 \\
\hline E2 & 7.9 & 2.2 & 1 & \begin{tabular}{|l|}
1.1 \\
\end{tabular} & \begin{tabular}{|l|}
3.8 \\
\end{tabular} & 13.6 & 30.9 & \begin{tabular}{|l|}
18.9 \\
\end{tabular} & 0.1 & 2.1 & \begin{tabular}{|l}
0.1 \\
\end{tabular} & 0.7 & 2.6 & 0.1 & 0.8 & 0.3 & 0.2 & 2.7 & \begin{tabular}{|l|}
11.1 \\
\end{tabular} \\
\hline Е3а & 8 & 2.2 & 1.5 & 0.9 & 1.9 & 13.6 & 32.9 & 21.1 & 0.1 & 10 & 0.3 & 0.6 & 2.8 & 0.1 & 1.4 & 0.4 & 0 & 3.5 & 6.3 \\
\hline E & & 5 & 1.6 & 2.2 & 8.4 & .2 & 27.2 & 16.1 & 0.1 & 2 & 3 & 8 & 6 & 0.1 & 1.4 & 3 & & $y$ & 10 \\
\hline E3c & & 3.3 & 1.6 & 1.7 & 5.2 & 17.7 & 24.6 & 15 & 0.2 & 2.8 & 0.6 & 1.2 & 3.5 & & 1.6 & 0.4 & & 2.3 & 8.4 \\
\hline$E 7^{a}$ & $8.4^{\mathrm{a}}$ & $3.7^{\mathrm{a}}$ & $1.5^{\mathrm{a}}$ & $2.6^{\mathrm{a}}$ & $8.8^{\mathrm{a}}$ & $11.4^{\mathrm{a}}$ & $30.2^{\mathrm{a}}$ & $16.8^{\mathrm{a}}$ & $0.1^{\mathrm{a}}$ & $1.7^{\mathrm{a}}$ & $0.1^{\mathrm{a}}$ & $0.7^{\mathrm{a}}$ & $2.4^{\mathrm{a}}$ & $0.1^{\mathrm{a}}$ & $1.3^{\mathrm{a}}$ & $0.3^{\mathrm{a}}$ & $0.3^{a}$ & $2.9^{\mathrm{a}}$ & $6.7^{\mathrm{a}}$ \\
\hline E13 & 11.6 & 5 & 2.1 & 3.5 & 8 & 14.7 & 22.1 & 12.7 & 0.1 & 2.4 & 0.2 & 1.1 & 3.1 & 0.1 & 1.6 & 0.5 & 0.4 & 3.4 & 7.4 \\
\hline $\mathrm{E} 18 / 1$ & 11.1 & 2.6 & 2 & 1 & 1.9 & 18.5 & 25.3 & 16.5 & 0.2 & 2.7 & 0.1 & 0.9 & 3.8 & 0.1 & 1.8 & 0.6 & 0.2 & 2.5 & 8.3 \\
\hline $\mathrm{E} 18 / 2$ & & 2.5 & 1.4 & 1.3 & 2.6 & 13 & 34.2 & 21 & 0.1 & 1.8 & 0.6 & 0.8 & 2.7 & 0.1 & 1.2 & 0.3 & 0.3 & 1.9 & 6.9 \\
\hline E19 & & 2.5 & 1.6 & 1.3 & 2.9 & 13.3 & 32.5 & 20.1 & 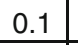 & 2.1 & 0.5 & 0.8 & 2.8 & 0.1 & 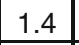 & 0.4 & & 4 & 5.4 \\
\hline E22 & 8 & 2.4 & 1.4 & 1.1 & 2.1 & 12.9 & 31.2 & 19.5 & 0.1 & 2 & 0.3 & 0.7 & 2.7 & 0.1 & 1.3 & 0.2 & 0.2 & 2 & 11.5 \\
\hline E27 & 7.2 & 2 & 1.4 & 0.8 & 1.9 & 13.8 & 32.2 & 21.1 & 0.1 & 2.5 & 0.1 & 0.8 & 2.8 & 0.2 & 1.4 & 0.3 & 0.2 & 4.1 & 7.3 \\
\hline E29 & 11 & 4.9 & 1.9 & 3.3 & 7.8 & 14.5 & 23.3 & 13 & 0.2 & 2.3 & 0.2 & 1 & 3 & & 0.7 & 0.4 & 0.5 & 3.2 & 7.8 \\
\hline$E 31^{a}$ & $7.3^{\mathrm{a}}$ & $4.2^{\mathrm{a}}$ & $1.4^{\mathrm{a}}$ & $2.7^{\mathrm{a}}$ & $9.4^{\mathrm{a}}$ & $11^{a}$ & $29.4^{\mathrm{a}}$ & $16.1^{\mathrm{a}}$ & $0.1^{\mathrm{a}}$ & $1.8^{\mathrm{a}}$ & $0.3^{\mathrm{a}}$ & $0.7^{\mathrm{a}}$ & $2.3^{\mathrm{a}}$ & $0.2^{\mathrm{a}}$ & $1.2^{\mathrm{a}}$ & $0.2^{\mathrm{a}}$ & $0.4^{\mathrm{a}}$ & $2.5^{\mathrm{a}}$ & $8.7^{\mathrm{a}}$ \\
\hline $\mathrm{H} 1$ & 16.9 & 7.5 & 3.5 & 3.9 & 7.1 & 10.1 & 29.2 & 10.9 & 0 & 0 & 0.2 & 1.9 & 4.9 & 0.7 & 0.7 & 0.3 & 0.5 & 0 & 1.8 \\
\hline $\mathrm{H} 2$ & 15.7 & 7.4 & 3.3 & 3.7 & 7 & 10.3 & 29.3 & 10.6 & 0 & 0 & 0.3 & 1.5 & 4.4 & 1.2 & 2.3 & 0.3 & . & 0.1 & 2.1 \\
\hline $\mathrm{H} 4$ & 16 & 8.4 & 2.3 & 3.5 & 6.7 & 10.3 & 29.2 & 11.5 & & & 0.6 & 1.6 & 4.4 & 0.9 & 0.9 & 0.4 & 0.5 & & 2.9 \\
\hline$F 1^{a}$ & $11.1^{\mathrm{a}}$ & $4.4^{\mathrm{a}}$ & $1.9^{\mathrm{a}}$ & $4.2^{\mathrm{a}}$ & $7.3^{\mathrm{a}}$ & $13^{a}$ & $30.4^{\mathrm{a}}$ & $11.8^{\mathrm{a}}$ & $0^{\mathrm{a}}$ & $0.8^{a}$ & $0.1^{\mathrm{a}}$ & $1.9^{\mathrm{a}}$ & $3.2^{\mathrm{a}}$ & $0.3^{\mathrm{a}}$ & $5.8^{\mathrm{a}}$ & $2.5^{\mathrm{a}}$ & $0.1^{a}$ & $0.4^{\mathrm{a}}$ & $0.6^{\mathrm{a}}$ \\
\hline $\mathrm{F}^{\mathrm{a}}$ & $12.8^{\mathrm{a}}$ & $3.6^{\mathrm{a}}$ & $3.2^{\mathrm{a}}$ & $4.3^{\mathrm{a}}$ & $7.6^{\mathrm{a}}$ & $9.3^{a}$ & $33.7^{\mathrm{a}}$ & $14^{\mathrm{a}}$ & $0.1^{\mathrm{a}}$ & $1.3^{\mathrm{a}}$ & $0.3^{\mathrm{a}}$ & $0.7^{\mathrm{a}}$ & $4^{a}$ & $0.2^{\mathrm{a}}$ & $1.6^{\mathrm{a}}$ & $0.4^{\mathrm{a}}$ & & $0.5^{\mathrm{a}}$ & $3.3^{\mathrm{a}}$ \\
\hline $\mathrm{F}^{\mathrm{a}}$ & $11^{\mathrm{a}}$ & $4^{a}$ & $3^{a}$ & $3.8^{\mathrm{a}}$ & $8.3^{\mathrm{a}}$ & $9.3^{a}$ & $32^{a}$ & $15.7^{\mathrm{a}}$ & $0.1^{\mathrm{a}}$ & $1.6^{\mathrm{a}}$ & $0.3^{\mathrm{a}}$ & $0.5^{\mathrm{a}}$ & $4.2^{\mathrm{a}}$ & $0.2^{\mathrm{a}}$ & $1.4^{\mathrm{a}}$ & $0.7^{\mathrm{a}}$ & $0.5^{a}$ & $0.03^{\mathrm{a}}$ & $3.2^{a}$ \\
\hline$F 4^{a}$ & $10.3^{a}$ & $5.5^{\mathrm{a}}$ & $2.9^{\mathrm{a}}$ & $5.8^{\mathrm{a}}$ & $7.6^{\mathrm{a}}$ & $11.7^{\mathrm{a}}$ & $31.2^{\mathrm{a}}$ & $11.7^{\mathrm{a}}$ & $0^{a}$ & $1.2^{\mathrm{a}}$ & $0.2^{\mathrm{a}}$ & $1^{\mathrm{a}}$ & $4.2^{\mathrm{a}}$ & $1.1^{\mathrm{a}}$ & $0.6^{\mathrm{a}}$ & $0.1^{\mathrm{a}}$ & $0.4^{a}$ & $0.9^{\mathrm{a}}$ & $3.6^{a}$ \\
\hline $\mathrm{F}^{\mathrm{a}}$ & $11.2^{\mathrm{a}}$ & $4^{a}$ & $1.8^{\mathrm{a}}$ & $3.1^{\mathrm{a}}$ & $7.8^{\mathrm{a}}$ & $9.8^{a}$ & $32.7^{\mathrm{a}}$ & $16.8^{\mathrm{a}}$ & $0^{a}$ & $1.3^{\mathrm{a}}$ & $0.3^{\mathrm{a}}$ & $0.5^{\mathrm{a}}$ & $4.2^{\mathrm{a}}$ & $0.3^{\mathrm{a}}$ & $0.9^{\mathrm{a}}$ & $0.6^{\mathrm{a}}$ & $0.7^{\mathrm{a}}$ & $0.1^{\mathrm{a}}$ & $3.7^{\mathrm{a}}$ \\
\hline $\mathrm{F} 7^{\mathrm{a}}$ & $11.5^{\mathrm{a}}$ & $4.4^{\mathrm{a}}$ & $2.3^{\mathrm{a}}$ & $4.4^{\mathrm{a}}$ & $7.7^{\mathrm{a}}$ & $12.7^{\mathrm{a}}$ & $30.9^{\mathrm{a}}$ & $12.9^{\mathrm{a}}$ & $0^{a}$ & $1^{a}$ & $0.3^{\mathrm{a}}$ & $1^{a}$ & $3.4^{\mathrm{a}}$ & $0^{a}$ & $6.4^{\mathrm{a}}$ & $0.3^{\mathrm{a}}$ & $0^{a}$ & $0.1^{\mathrm{a}}$ & $0.4^{a}$ \\
\hline $\mathrm{Fg}^{\mathrm{a}}$ & $10.7^{\mathrm{a}}$ & $3.5^{\mathrm{a}}$ & $2.1^{\mathrm{a}}$ & $4.3^{\mathrm{a}}$ & $8.3^{\mathrm{a}}$ & $9.2^{a}$ & $34.2^{\mathrm{a}}$ & $14.8^{\mathrm{a}}$ & $0.1^{\mathrm{a}}$ & $1.4^{\mathrm{a}}$ & $0.5^{\mathrm{a}}$ & $0.6^{\mathrm{a}}$ & $4.1^{\mathrm{a}}$ & $0^{a}$ & $1.6^{\mathrm{a}}$ & & & $3.9^{\mathrm{a}}$ & $3^{a}$ \\
\hline $\mathrm{F} 10^{\mathrm{a}}$ & $10.7^{\mathrm{a}}$ & $3.2^{\mathrm{a}}$ & $2.6^{a}$ & $4^{a}$ & $8.2^{\mathrm{a}}$ & $9.4^{\mathrm{a}}$ & $32.4^{\mathrm{a}}$ & $15.7^{\mathrm{a}}$ & $0.1^{\mathrm{a}}$ & $1.5^{\mathrm{a}}$ & $0.5^{\mathrm{a}}$ & $0.5^{\mathrm{a}}$ & $4.2^{\mathrm{a}}$ & $0.2^{\mathrm{a}}$ & $1.4^{\mathrm{a}}$ & $0.4^{\mathrm{a}}$ & & $0.4^{\mathrm{a}}$ & $3.5^{\mathrm{a}}$ \\
\hline
\end{tabular}

a Specimens with "good collagen" quality 
Table $5 \mathrm{Wt} \%, \mathrm{~N} \%$ and $\mathrm{C} \%, \mathrm{C} / \mathrm{N}$-molar and $\mathrm{D} / \mathrm{L}$-asp-values of the archaeological bones

\begin{tabular}{|c|c|c|c|c|c|}
\hline sample & weight $\%$ & $\mathbf{N}(\%)$ & C (\%) & C/N molar & D/L-asp \\
\hline Gü2 ${ }^{a}$ & $0.3^{\mathrm{a}}$ & $13.29^{\mathrm{a}}$ & $43.25^{a}$ & $3.798^{a}$ & $0.0301^{a}$ \\
\hline Gü3 ${ }^{a}$ & $0.17^{\mathrm{a}}$ & $3.285^{\mathrm{a}}$ & $13.39^{\mathrm{a}}$ & $4.755^{a}$ & $0.0265^{a}$ \\
\hline NC12 & 1.07 & 12.89 & 36.2 & 3.28 & 0.036 \\
\hline NC16 & 1.06 & 10.2 & 42 & 3.22 & 0.0513 \\
\hline $\mathrm{NC17}$ & 0.41 & 4.107 & 35.39 & 3.14 & 0.0596 \\
\hline NC18 & 1.81 & 8.945 & 38.36 & 3.32 & \begin{tabular}{|l|}
0.0477 \\
\end{tabular} \\
\hline$P 1^{a}$ & $2.45^{\mathrm{a}}$ & $13.66^{a}$ & $46.24^{\mathrm{a}}$ & $3.525^{\mathrm{a}}$ & $0.0455^{\mathrm{a}}$ \\
\hline$P 2^{a}$ & $4.51^{a}$ & $12.89^{\mathrm{a}}$ & $52.48^{\mathrm{a}}$ & $3.856^{a}$ & $0.0377^{a}$ \\
\hline $\mathrm{P}^{\mathrm{a}}$ & $5.5^{\mathrm{a}}$ & $15.28^{\mathrm{a}}$ & $54.68^{\mathrm{a}}$ & $3.531^{a}$ & $0.0426^{a}$ \\
\hline $\mathrm{P} 4^{\mathrm{a}}$ & $8.05^{a}$ & $14.72^{\mathrm{a}}$ & $45.5^{\mathrm{a}}$ & $3.509^{a}$ & $0.043^{\mathrm{a}}$ \\
\hline ES & 3.53 & 16.62 & 54.9 & 3.853 & 0.0482 \\
\hline$T 1^{\mathrm{a}}$ & $1.48^{\mathrm{a}}$ & $13.81^{\mathrm{a}}$ & $40.53^{\mathrm{a}}$ & $3.424^{a}$ & $0.0411^{a}$ \\
\hline $\mathrm{T}^{\mathrm{a}}$ & $0.7^{\mathrm{a}}$ & $15.43^{\mathrm{a}}$ & $44.13^{\mathrm{a}}$ & $3.336^{a}$ & \\
\hline$T 3^{a}$ & $6.46^{a}$ & $13.85^{\mathrm{a}}$ & $46.02^{\mathrm{a}}$ & $3.878^{a}$ & $0.0313^{a}$ \\
\hline$T 4^{\mathrm{a}}$ & $7.93^{a}$ & $14.3^{\mathrm{a}}$ & $43.54^{\mathrm{a}}$ & $3.551^{a}$ & $0.0331^{a}$ \\
\hline$T 5^{a}$ & $3.49^{a}$ & $14.57^{\mathrm{a}}$ & $44.04^{\mathrm{a}}$ & $3.526^{a}$ & $0.0318^{a}$ \\
\hline$T 6^{a}$ & $0.31^{a}$ & $11.49^{\mathrm{a}}$ & $31.84^{\mathrm{a}}$ & $3.232^{a}$ & $0.0397^{a}$ \\
\hline$T 7^{\mathrm{a}}$ & $2.36^{a}$ & $12.06^{\mathrm{a}}$ & $39.32^{\mathrm{a}}$ & $3.806^{a}$ & $0.037^{\mathrm{a}}$ \\
\hline$T 8^{\mathrm{a}}$ & $5.38^{a}$ & $14.26^{\mathrm{a}}$ & $42.49^{\mathrm{a}}$ & $3.475^{\mathrm{a}}$ & $0.0358^{a}$ \\
\hline $\mathrm{Tg}^{\mathrm{a}}$ & $3.84^{a}$ & $15.03^{\mathrm{a}}$ & $45.6^{\mathrm{a}}$ & $3.541^{a}$ & $0.0352^{a}$ \\
\hline E1 & 1.02 & 13.46 & 42.98 & 3.73 & 0.0391 \\
\hline E2 & 1.81 & 13.16 & 41.28 & 3.66 & \begin{tabular}{|l|}
0.0486 \\
\end{tabular} \\
\hline E3a & 1.64 & 15.68 & 49.64 & 3.69 & 0.0386 \\
\hline E3b & 2.44 & 13.12 & 46.93 & 4.15 & \begin{tabular}{|l|}
0.0528 \\
\end{tabular} \\
\hline E3c & 3.51 & 14.73 & 44.1 & 3.49 & 0.0463 \\
\hline$E 7^{a}$ & $1.63^{\mathrm{a}}$ & $11.71^{\mathrm{a}}$ & $39.07^{a}$ & $3.89^{a}$ & $0.0349^{a}$ \\
\hline E13 & 1.51 & 12.05 & 36.54 & 3.54 & 0.0445 \\
\hline $\mathrm{E} 18 / 1$ & 3.28 & 13.73 & 40.73 & 3.46 & 0.0492 \\
\hline $\mathrm{E} 18 / 2$ & 2.65 & 12.56 & 38.81 & 3.61 & 0.041 \\
\hline E19 & 1.5 & 15.48 & 59.2 & 4.46 & 0.0488 \\
\hline E22 & 1.66 & 15.74 & 47.58 & 3.53 & 0.053 \\
\hline E27 & 1.08 & 14.9 & 49.07 & 3.84 & 0.0463 \\
\hline E29 & 2.06 & 8.36 & 26.84 & 3.75 & \begin{tabular}{|l|}
0.0686 \\
\end{tabular} \\
\hline E31 ${ }^{a}$ & $2.2^{\mathrm{a}}$ & $5.03^{a}$ & $16.69^{\mathrm{a}}$ & $3.87^{a}$ & $0.0388^{a}$ \\
\hline $\mathrm{H} 1$ & 17.68 & 16.97 & 54.65 & 3.756 & 0.0275 \\
\hline $\mathrm{H} 2$ & 14.86 & 14.96 & 45.28 & 3.532 & 0.0275 \\
\hline $\mathrm{H} 4$ & 12.78 & 14.35 & 43.29 & 3.52 & 0.0577 \\
\hline$F 1^{a}$ & $3.31^{a}$ & $16.58^{\mathrm{a}}$ & $49.41^{\mathrm{a}}$ & $3.477^{a}$ & $0.0275^{a}$ \\
\hline $\mathrm{F}^{\mathrm{a}}$ & $1.92^{\mathrm{a}}$ & $13.09^{\mathrm{a}}$ & $40^{a}$ & $3.565^{a}$ & $0.0352^{a}$ \\
\hline $\mathrm{F}^{\mathrm{a}}$ & $7.59^{a}$ & $13.57^{\mathrm{a}}$ & $40.75^{\mathrm{a}}$ & $3.504^{a}$ & $0.0285^{a}$ \\
\hline $\mathrm{F} 4^{\mathrm{a}}$ & $7.3^{\mathrm{a}}$ & $15.12^{\mathrm{a}}$ & $44.63^{\mathrm{a}}$ & $3.443^{a}$ & $0.0358^{a}$ \\
\hline $\mathrm{F}^{\mathrm{a}}$ & $0.75^{a}$ & $11.78^{\mathrm{a}}$ & $33.57^{\mathrm{a}}$ & $3.324^{a}$ & $0.028^{a}$ \\
\hline$F 6^{a}$ & $4.84^{a}$ & $21.94^{\mathrm{a}}$ & $42.22^{\mathrm{a}}$ & $3.841^{a}$ & $0.0331^{a}$ \\
\hline $\mathrm{F} 7^{\mathrm{a}}$ & $5.56^{a}$ & $16.8^{\mathrm{a}}$ & $49.05^{\mathrm{a}}$ & $3.405^{\mathrm{a}}$ & $0.0248^{a}$ \\
\hline $\mathrm{Fg}^{\mathrm{a}}$ & $7.5^{\mathrm{a}}$ & $15.1^{\mathrm{a}}$ & $44.52^{\mathrm{a}}$ & $3.439^{a}$ & $0.0341^{a}$ \\
\hline $\mathrm{F} 10^{\mathrm{a}}$ & $8.8^{\mathrm{a}}$ & $17.43^{\mathrm{a}}$ & $51.25^{\mathrm{a}}$ & $3.431^{a}$ & $0.0295^{a}$ \\
\hline
\end{tabular}

a Specimens with "good collagen" quality

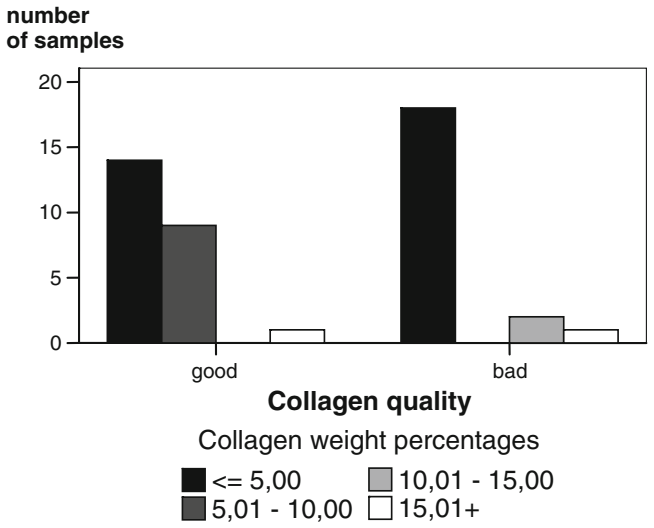

Fig. 5 Collagen weight percentages of the archaeological samples presented separately according to good and poor collagen quality

increase of $\delta^{13} \mathrm{C}$ by $3 \%$ would indicate a certain proportion of $\mathrm{C}_{4}$-plants or marine resources in the food of an individual coming from an otherwise $\mathrm{C}_{3}$-plant dominated habitat. Strikingly, the direction of these shifts of the isotopic ratios in the highly degraded samples 16 and 32 is opposite to the one reported after experimental microbial degradation of modern marten bone collagen, where a decrease of the $\delta^{13} \mathrm{C}$-values and a fundamental increase of the $\delta^{15} \mathrm{~N}$-values was evidenced (Balzer et al. 1997).

Contrary to microbial decomposition, which obviously selectively metabolizes amino acids which play a role in the microbial metabolism, the kinetics of peptide bond cleavage are a likely explanation for the phenomenon, although also chemical hydrolysis finally leads to a non-random loss of certain amino acids. Chemical bonds in molecules containing heavier isotopes are commonly stronger and more stable than those formed by lighter isotopes, but they are also less easily formed.

Normally, the heavy isotope should preferably be retained in the degraded sample in the course of peptide bond cleavage (Bada et al. 1989). However, in our study,

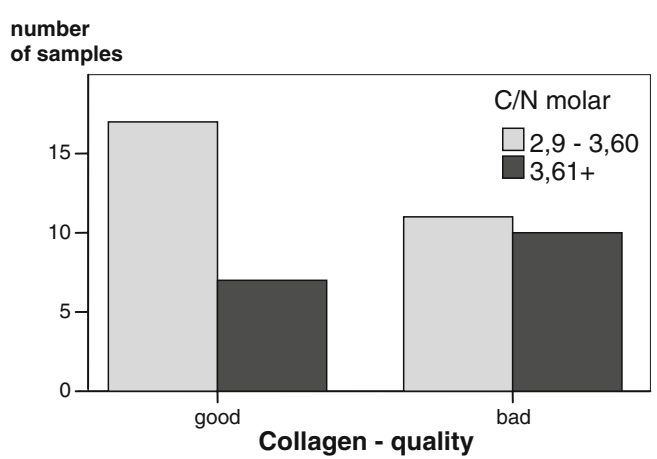

Fig. 6 Number of archaeological samples with $\mathrm{C} / \mathrm{N}$-molar ratios of 2.9-3.6 and above, and their classification according to good and poor collagen quality 


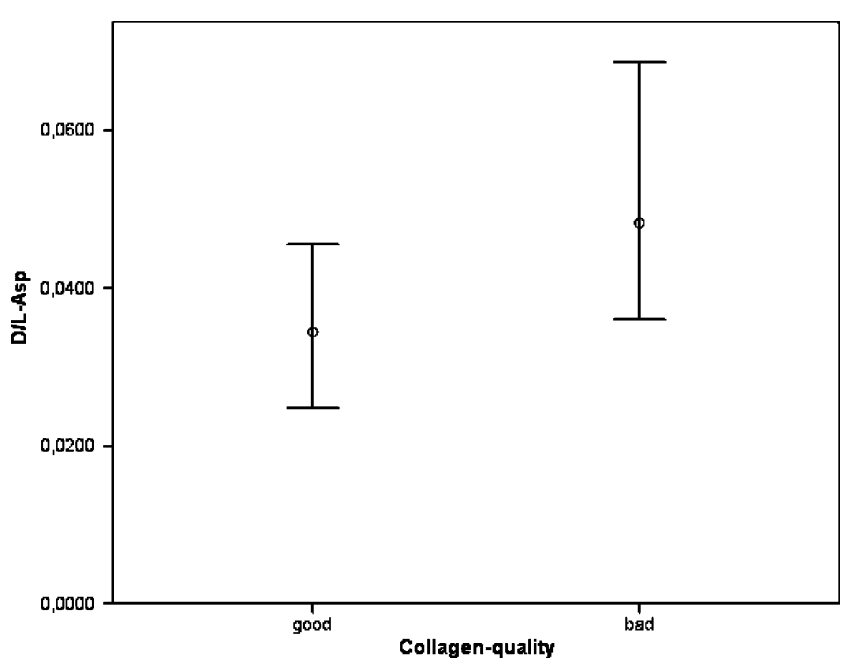

Fig. 7 Mean (circle), maximum (upper limit) and minimum (lower limit) of the $\mathrm{D} / \mathrm{L}$-Asp values of the archaeological material according to good and poor collagen quality

this assumption holds true for ${ }^{13} \mathrm{C}$ only, while in contrast, $\delta^{15} \mathrm{~N}$ is depleted.

As depicted in Table 3, heat induced changes in the gelatine amino acid composition after termination of the experiment were largest (more than $5 \mathrm{nmol} \%$ deviation of the mean value and outside of the range, see Table 3 ) in the case of threonine (relative increase by $7.3 \mathrm{nmol} \%$ ) and glycine (decrease by $5.48 \mathrm{nmol} \%$ ). According to Ambrose (1993), single amino acid $\delta^{15} \mathrm{~N}$ is $-8.5 \%$ or threonine, and only $-2.1 \%$ for glycine, which will account for the global $\delta^{15} \mathrm{~N}$ value of the extracted gelatine to decrease. A contamination of the samples, e.g. with bacterial biomass, which would also lead to altered initial values (Grupe 2001), can be ruled out on the basis of the experimental design, the process of gelatine extraction, and the resulting amino acid profiles where no microbial amino acids like, e.g. pimelic acid, were found.

It could be shown that, contrary to the collagen weight percentages and the aspartic acid racemization, the commonly used quality criteria $\mathrm{C} \%, \mathrm{~N} \%, \mathrm{C} / \mathrm{N}$ molar and also the amino acid composition remain very stable during the experimental degradation. Only highly degraded samples with incubation times of more than eight days show drastic changes of these criteria and, accordingly, shifts of the stable isotopic values. These results confirm the assumption by Dobberstein et al. (2008), who examined experimentally degraded teeth. Although collagen was gradually lost, the collagen molecules remaining in the specimen still kept an intact molecular composition until a critical degradation state, which was reached between eight and twelve days in our study and a collagen content of less than three weight percentages.

For any concluding statement, however, the observed tendencies in the chemical degradation processes, especially around the time of the critical point, ought to be reinforced by further investigations. It should be emphasized though that decomposition processes can also lead to significantly altered isotopic values in the bone collagen without microbial involvement.

Diagenetic modification of the archaeological material

A drop out of single amino acids in the amino acid profile was frequently evidenced in the archaeological samples. Similar to the findings obtained by Grupe et al. (2000), mainly amino acids which are rich in carbon are lost, indicative of a preferred degradation of amino acids with many carbon atoms as a source of energy for microorganisms. Generally, this process should lead to a decrease of the $\mathrm{C} / \mathrm{N}$-ratios, since the amino acids lost from the bone have higher $\mathrm{C} / \mathrm{N}$-ratios (also see Balzer et al 1997). In contrast, all specimens with $\mathrm{C} / \mathrm{N}$-molar-values outside the range defined by DeNiro (1985), show always increased and never decreased $\mathrm{C} / \mathrm{N}$-molar values. This indicates either contamination with exogenous carbon or degradation of amino acids with few carbon atoms in relation to nitrogen, like glycine (cf. temperature experiment).

While these results seem to be contradictory at first glance (microbial degradation of the samples, but increased $\mathrm{C} / \mathrm{N}$-molar values), they indicate the complex interaction of many parameters that are capable of influencing the $\mathrm{C} / \mathrm{N}$ molar ratio. A simultaneous or successive influence of microbial diagenesis (decrease of $\mathrm{C} / \mathrm{N}$-ratios; cf. Grupe et al. 2000) and chemical diagenesis or contamination (increase of $\mathrm{C} / \mathrm{N}$-ratios) could lead to almost ideal $\mathrm{C} / \mathrm{N}$ ratios in samples that are even be identified as "collagenlike" by amino acid analysis (e.g. Lösch et al. 2006). This way, an explanation is offered for the existence of archaeological specimens which exhibit an amino acid profile different from fresh collagen (poor collagen quality), but at the same time have $\mathrm{C} / \mathrm{N}$ molar values within the range of ratios defined for well-preserved collagen in the literature (see Fig. 6).

The existence of samples with good collagen quality but highly altered $\mathrm{C} / \mathrm{N}$-molar values may be due to the sample processing procedure. Van Klinken (1999) states that as much as $20-50 \%$ of the preserved collagen cannot be hydrolyzed due to diagenetic alterations and thus will not show up in amino acid analysis. Accordingly, an animo acid profile would suggest a good collagen preservation status, although altered collagen is still present in the whole sample which might have an influence on both the $\mathrm{C} / \mathrm{N}$ molar and the isotopic ratios. Such a possibility cannot be ruled out with regard to our samples. No correlation was found between the weight percentages of carbon and nitrogen in the gelatine and the quality of the amino acid profiles. 
Moreover, no statistical association between percent collagen content and collagen quality was found, contrary to Ambrose $(1990,1993)$. However, also Ambrose (1990) notes that samples with collagen percentages below 5\% have frequently less, at the same time, well preserved collagen, which is also seen as a tendency in our study (cf. Fig. 5). The mere amount of unaltered collagen preserved in bone seems to have little influence on its quality.

The degree of aspartic acid racemization (measured in the $\mathrm{HCl}$ insoluble fraction of bone, see methods) has a tendency to correlate with the amino acid composition of the gelatine: Samples with poor collagen quality have higher D/L-asp-values always above 0.036 (cf. Fig. 7). Certainly, this relationship is connected with the observed highly significant negative correlation between collagen weight percentage (which also shows a relationship to the collagen quality) and the D/L-asp-value - if the collagen weight percentages are low, the $\mathrm{D} / \mathrm{L}$-asp-value seems to be higher in the most cases. The cumulative fragmentation of collagen is responsible for both the loss of collagen fragments (and so the decreased collagen weight percentages) and the increasing D/L-asp value because D-asp can accumulate at the free ends of the fragmented collagen helix (compare the experimentally degraded bone). However, as already mentioned, the D/L-asp-values also depend on the rate of loss of the denatured (and racemized) residues. In case of a considerable loss of progressively racemized collagen fragments in a sample, both the D/L-asp-value and the collagen weight percentages will decrease. Such a scenario probably explains the weak correlation coefficient of only 0.374 , which means that the linear relationship between the $\mathrm{D} / \mathrm{L}$-asp values and the collagen weight percentages is not a very close one.

This dependency of the D/L-asp-value from the leaching rate can also contribute to an explanation of why samples with good collagen quality have higher D/L-asp-values on average. If there is a loss of highly degraded collagen fragments (progressively racemized and with altered amino acid profiles), the intact collagens fragments with unaltered amino acid profiles remain, and the $\mathrm{D} / \mathrm{L}$-asp-value is low.

\section{Super collagen}

The samples of the Hemmingstedt site constitute a special series, since all specimens exhibited an amino acid profile with elevated hydroxyproline concentrations, just like sample 2 of the temperature experiment. However, although the latter exhibited such a unique amino acid profile, the stable isotope ratios were unchanged. This special amino acid profile in archaeological bones, sometimes labeled as "super collagen", has been described previously in the literature (Elster et al. 1991; Grupe and Turban-Just 1998). According to Elster et al. (1991), it is brought about by an improper sample processing - since glycine is more volatile than hydroxyproline, excessive evaporation of the hydrolyzed gelatine will lead to a loss of glycine, resulting in a relative surplus of hydroxyproline. Such a preparation artifact cannot be ruled out for the Hemmingstedt samples. Since stable isotope analysis does not include such a preparation step, it is most probable that a seemingly altered amino acid profile is accompanied by unaltered stable isotope ratios (see also sample 2 of the temperature experiment).

\section{Implications for collagen quality criteria}

The analysis of stable isotopes as an important and widely applied archaeometric method depends on qualitatively unaltered collagen or at least a collagen well enough preserved that the $\delta^{13} \mathrm{C}$ and $\delta^{15} \mathrm{~N}$ values remain unchanged. The most frequently used criteria for the decision whether an archaeological bone will still have retained its original biological isotopic signal are the $\mathrm{C} / \mathrm{N}$-molar value, the collagen weight percentages, and the weight percentages of carbon and nitrogen. All these criteria are quick and easy to obtain, since modern mass spectrometers automatically report $\mathrm{C} / \mathrm{N}, \mathrm{C} \%$ and $\mathrm{N} \%$ together with the isotopic ratios. Our results obtained from the heating experiment and from the archaeological material provide some more information with regard to the usefulness of these quality criteria.

First of all it should be noted that a poor collagen quality assessed by amino acid analysis serves as a touchstone because it can be readily assumed that in cases of a modified amino acid composition, the samples will also exhibit shifts of the $\delta$-values. Conversely, it cannot be concluded that an unaltered amino acid profile always guarantees unaltered isotopic data, because of the risk of undetected contamination and non-hydrolysable collagen components (see the following).

In our study, the bone's collagen content in $\mathrm{wt} \%$ does not permit any certain conclusion on the collagen's state of preservation. In the temperature experiment, the first alteration of stable isotope values was depicted at collagen weight percentages below $0.2 \%$, while in the archaeological material, highly altered amino acid profiles were found in all collagen $\mathrm{wt} \%$ categories, even though they accumulate in samples with a weight proportion below 5\%. The collagen content in $\mathrm{wt} \%$ thus cannot serve as a general quality indicator. The assumption that a certain threshold of retrievable collagen can be presumed to reflect the minimum level of well-preserved collagen cannot be verified in this study either. Contrary to Ambrose (1993), there is no accumulation of samples with altered amino acid profiles with collagen contents below $1 \mathrm{wt} \%$. Unfortunately, we cannot comment on the findings by van Klinken (1999), who sets this limit to even $0.5 \mathrm{wt} \%$, since there were hardly 
any archaeological samples with a collagen content this low in our study. However, the results from the temperature experiment do support van Klinken's (1999) statement.

No significant relationship between the weight proportions of carbon and nitrogen in the archaeological bone material and the collagen quality was found in our study. Contrary to Ambrose (1993), modified amino acid profiles and altered isotopic values were frequently found in samples that otherwise had carbon and nitrogen proportions beyond 3 and $1 \%$, respectively. This is confirmed by the temperature experiment, where chemical degradation of collagen was evidenced by altered isotopic values at a $\mathrm{C} \%$ of $11.5 \%$ (sample 16) a N\% of $6 \%$ (sample 12). Therefore, also the carbon and nitrogen weight proportions in collagen are not necessarily a reliable indicator for the validity of isotopic data; however, they still serve as useful indicators for contamination. Highly increased carbon and nitrogen weight proportions in collagen indicate exogenous substances.

The most important and most frequently quoted quality criterion, however, is the $\mathrm{C} / \mathrm{N}$-molar ratio, which is even taken as the only criterion for the assessment of the collagen quality in many studies (e.g. Dupras et al. 2001; Harrison and Katzenberg 2003; Jay et al. 2008; McGovernWilson and Quinn 1996; Noe-Nygaard et al. 2005; Ogrinc and Budja 2005; Schurr 1997; Sealy et al. 1992). In our chemically degraded samples, unchanged stable isotope ratios coincide with $\mathrm{C} / \mathrm{N}$-molar values from 3.23 up to 4.17 . This may indicate that the range of 2.9-3.6 as defined by DeNiro (1985) could be extended, since samples with C/Nratios higher than 3.6 still retained the initial stable isotopic signature. In fact, $\mathrm{C} / \mathrm{N}$-molar ratios up to 3.8 have been measured in modern fish bone (Grupe et al. 2003), and stable isotope data from archaeological bones with $\mathrm{C} / \mathrm{N}$ ratios up to 4.0 have also been occasionally worked with (e. g. Coltrain et al. 2004). However, the analysis of the archaeological material showed that about half of the investigated samples with poor collagen quality (and so most likely shifted stable isotope ratios) have $\mathrm{C} / \mathrm{N}-$ molar ratios in this very range of 2.9-3.6. Equally, a limitation of the permitted variability according to van Klinken (1999) does not change the situation.

Accordingly, the $\mathrm{C} / \mathrm{N}$-molar ratio is not suitable for excluding all samples with diagenetically altered isotopic ratios from a set of samples; although this has been suggested as early as the late eighties (Schoeninger et al. 1989), ("neither the superficial appearance, the percentage of residue extracted, nor the $\mathrm{C}$ to $\mathrm{N}$ ratios can be used to predict how well collagen is preserved"), the $\mathrm{C} / \mathrm{N}$ ratio remains an undisputed quality criterion by many researchers (see the following). A review of the published literature quickly reveals other early statements on the limited suitability of $\mathrm{C} / \mathrm{N}$-ratios for the detection of possible diagenetically altered stable isotopic ratios (cf. DeNiro
1985; DeNiro and Weiner 1988; Nicholson 1998), although contaminations will be recognized in most cases.

Certainly, expedient for a test concerning the validity of stable isotopic values is the establishment of an amino acid profile, because any modifications of the collagen amino-acid composition are directly depicted. However, also this quality criterion is not totally free of pitfalls. Not in all cases will contaminations with exogenous substances be recognized, especially when one is only analyzing the physiological amino acids (which is the normal laboratory routine), thereby excluding the detection of microbial amino acids or breakdown products of physiological amino acids. Also the risk remains that non-hydrolyzable fractions may be present in the collagen/extracted residue, e.g. by colloid formation aided by humic substances. In this case, a collagenous amino acid profile will go hand in hand with diagenetically altered stable isotopic values.

Since no quality criterion taken alone is sufficient for the acceptance of stable isotopic data obtained from archaeological collagen as being valid, we recommend the routine establishment of amino acid profiles together with the figures of $\mathrm{C} \%, \mathrm{~N} \%$, and $\mathrm{C} / \mathrm{N}$-molar which are conveniently obtained from the mass spectrometry. We also conclude that the range of acceptable $\mathrm{C} / \mathrm{N}$-molar ratios may be widened and include ratios between 3.6 and 4.0 as well, as long as the other quality criteria are fulfilled. $\mathrm{C} / \mathrm{N}$-molar ratios lower than 2.8 (Hedges 2000), however, must be considered noncollagenous and stable isotopic data from such extracts will not be reliable (Schoeninger et al. 1989). The racemization of aspartic acid shows a tendency to be accelerated in bone samples with altered collagen. If this method offers the possibility to unambiguously asses the collagen quality for stable isotope analyses will be tested in ongoing studies.

Acknowledgments We thank Prof. Dr. S. Ritz-Timme, Dr. R. Dobberstein (Forensic Department of the University of Düsseldorf) and particularly Dr. H.W. Schütz (Forensic Department of the University of Kiel) for the help regarding the racemization analyses.

\section{References}

Ambrose SH (1990) Preparation and characterization of bone and tooth collagen for isotopic analysis. J Arch Sci 17:431-451

Ambrose SH (1993) Isotopic analysis of palaeodiets: methodical and interpretive considerations. In: Sandford MK (ed) Investigation of ancient human tissue: chemical analysis in anthropology. Gordon \& Breach, New York, pp 59-130

Armstrong WG, Halstead LB, Reed FB, Wood L (1983) Fossil proteins in vertebrate calcified tissues. Phil Trans R Soc B:301-343

Bada JL, Schoeninger MJ, Schimmelmann A (1989) Isotopic fractionation during peptide bond hydrolysis. Geochim Cosmochim Acta 53:3337-3341

Bada JL, Wang SW, Hamilton H (1999) Preservation of key biomolecules in the fossil record: current knowledge and future challenges. Phil Trans R Soc B 354:77-87 
Balzer A, Gleixner G, Grupe G, Schmidt HL, Schramm S, Turban-Just S (1997) In vitro decomposition of bone collagen by soil bacteria: the implication for stable isotope analysis in archaeometry. Archaeometry 39:415-429

Child AM (1995) Towards an understanding of the microbial decomposition of archaeological bone in the burial environment. J Arch Sci 22:165-174

Collins MJ, Riley MS, Child AM, Turner-Walker G (1995) A basic mathematical simulation of the chemical degradation of ancient collagen. J Arch Sci 22:175-183

Collins MJ, Waite ER, van Duin ACT (1999) Predicting protein decomposition: the case of aspartic acid racemization kinetic. Phil Trans R Soc B 354:51-64

Collins MJ, Nielsen-Marsh CM, Hiller J, Smith CI, Roberts JP (2002) The survival of organic matter in bone: a review. Archaeometry 44:383-394

Coltrain JB, Harris JM, Cerling TE, Ehrleringer JR, Dearing MD, Ward J, Allen J (2004) Rancho La Brea stable isotope biogeochemistry and its implications for the palaeoecology of late Pleistocene, coastal southern California. Palaeogeogr Palaeoclimatol Palaeoecol 205:199-219

Czermak A, Ledderose A (2004) Getrennt und Gemeinsam: Zur gesellschaftlichen Gliederung eines frühmittelalterlichen Separatfriedhofs. Erste Ergebnisse einer archäologisch-anthropologischen Synthese. Doc Archaeobiol 2:71-95

Dobberstein RC, Huppertz J, von Wurmb-Schwark N, Ritz-Timme S (2008) Degradation of biomoleculaes in artificially and naturally aged teeth: implications for age estimation based on aspartic acid racemization and DNA analysis. Forensic Sci Int 179:181-191

DeAlbuquerque Leinenbach G, Mályusz V, Schröder I (2000) Anthropologische Befunde zur Schlacht bei Hemmingstedt (mit anhängendem Glossar). Arch Nachr S-H 11:58-83

DeNiro MJ (1985) Postmortem preservation and alteration of in vivo bone collagen isotope ratios in relation to paleodietary reconstruction. Nature 317:806-809

DeNiro MJ, Weiner S (1988) Chemical, enzymatic and spectroscopic characterization of "collagen" and other organic fractions from prehistoric bones. Geochim Cosmochim Acta 52:2197-2206

Dupras TL, Schwarcz HP, Fairgrieve IS (2001) Infant feeding and weaning practices in Roman Egypt. Am J Phys Anthropol 115:204-212

El Mansouri M, El Fouikar A, Saint-Martin B (1996) Correlation between $14 \mathrm{C}$ ages and aspartic acid racemization at the upper Palaeolithic site of the Abri Pataud (Dordogne, France). J Arch Sci 23:803-809

Elster H, Gil AVE, Weiner S (1991) Amino acid racemization of fossil bone. J Arch Sci 18:605-617

Gebhardt KE (2003) Anthropologische Untersuchung der Skelettfunde. In: Witte F (ed) Archäologie in Flensburg. Ausgrabungen am Franziskanerkloster, Gesellschaft für Flensburger Stadtgeschichte e. V., Flensburg, Germany, pp 76-103

Grupe G (1992) Analytisch-chemische Methoden in der prähistorischen Anthropologie: Spurenelemente und stabile Isotope. In: Knußmann R (ed) Anthropologie. Handbuch der vergleichenden Biologie des Menschen, Band II: Allgemeine Anthropologie. Fischer, Stuttgart, Germany, pp 66-73

Grupe G (2001) Archaeological microbiology. In: Brothwell DR, Pollard AM (eds) Handbook of archaeological sciences. Wiley, New York, pp 351-363

Grupe G, Turban-Just S (1998) Amino acid composition of degraded matrix collagen from archaeological human bone. Anthropol Anz $56: 213-226$

Grupe G, Balzer A, Turban-Just S (2000) Modeling protein diagenesis in ancient bone: towards a validation of stable isotope data. In: Ambrose SH, Katzenberg MA (eds) Biogeochemical approaches to paleodietary analysis. Advances in Archaeological and Museum Science, vol 5. Plenum, New York, pp 173-187
Grupe G, Mikic Z, Peters J, Manhart H (2003) Vertebrate food webs and subsistence strategies of Meso- and Neolithic populations of central Europe. Doc Archaeobiol 1:193-213

Harrison RG, Katzenberg MA (2003) Paleodiet studies using stable carbon isotopes from bone apatite and collagen: examples from Southern Ontario and San Nicolas Island, California. J Anthrop Arch 22:227-244

Hedges REM (2000) Appraisal of radiocarbon dating of kiore bones (Pacific rat Rattus exulans) in New Zealand. J Roy Soc New Zealand 30:385-389

Hedges REM (2002) Bone diagenesis: an overview of processes. Archaeometry 44:319-328

Hirsch K (2001) Das Megalithgrab von Matzwitz, Kr. Plön: Spiegel des Lebens und Fenster zum Jenseits? Arch Info 24(2):239-246

Jay M, Fuller BT, Richards MP, Knüsel CJ, King SS (2008) Iron age breastfeeding practices in Britain: istopic evidence from Wetwang Slack, East Yorkshire. Am J Phys Anthropol 136:327-337

Koch PL, Behrensmeyer AK, Stott AW, Tuross N, Evershed RP (2001) The effects of weathering on the stable isotope composition of bones. Anc Biomol 3:117-134

Lee-Thorp JA, Sealy JC, van der Merwe NJ (1989) Stable carbon isotope ratio differences between bone collagen and bone apatite, and their relationship to diet. J Arch Sci 16:585-599

Lösch S, Grupe G, Peters J (2006) Stable isotopes and dietary adaptations in humans and animals at Pre-Pottery Neolithic Nevalı Çori, SE-Anatolia. Am J Phys Anthropol 131:181-193

Masters P (1987) Preferential preservation of noncollagenous protein during bone diagenesis: implications for chronometric and stable isotopic measurement. Geochim Cosmochim Acta 51:3209-3214

McGovern-Wilson R, Quinn C (1996) Stable Isotope analysis of ten individuals from Afetna, Saipan, northern Mariana Island. J Arch Sci 23:59-65

Nelson BK, DeNiro MJ, Schoeninger MJ, DePaolo DJ (1986) Effects of diagenesis on strontium, carbon, nitrogen and oxygen concentration and isotopic composition of bone. Geochim Cosmochim Acta 50:1941-1949

Nicholson RA (1998) Bone degradation in a compost heap. J Arch Sci 25:393-403

Nielsen-Marsh CM, Gernaey A, Turner-Walker G, Hedges REM, Pike A, Collins MJ (2000) The chemical degradation of bone. In: Cox M, Mays S (eds) Human osteology in archaeology and forensic science. Greenwich Medical Media, London, pp 439-454

Noe-Nygaard N, Price TD, Hede SU (2005) Diet of aurochs and early cattle in southern Scandinavia: evidence from $15 \mathrm{~N}$ and $13 \mathrm{C}$ stable isotopes. J Arch Sci 32:855-871

Ogrinc N, Budja M (2005) Paleodietary reconstruction of a Neolithic population in Slovenia: a stable isotope approach. Chem Geol 218:103-116

Poinar HN, Höss M, Bada JL, Pääbo S (1996) Amino acid racemization and the preservation of ancient DNA. Science 272:864-866

Ritz-Timme S (1999) Lebensaltersbestimmung aufgrund des Razemisierungsgrades von Asparaginsäure, Grundlagen, Methodik, Möglichkeiten, Grenzen, Anwendungsbereiche. In: Berg S, Brinkmann B (eds) Arbeitsmethoden der medizinischen und naturwissenschaftlichen Kriminalistik. Schmidt-Römhild, Lübeck, Germany

Roberts SJ, Smith CI, Millard A, Collins MJ (2002) The taphonomy of cooked bone: characterizing boiling and its physico-chemical effects. Archaeometry 44:485-494

Schoeninger MJ, Moore KM, Murray ML, Kingston JD (1989) Detection of bone preservation in archaeological and fossil samples. Appl Geochem 4:281-292

Schröder I, Dietrich M, Koch J, Weidner M (1998) Anthropologische Untersuchung von 27 spätrömischen Skeletten aus einem Gräberfeld an der Medardstraße in Trier. Trierer Zeitschrift 61:343-364 
Schurr MR (1997) Stable nitrogen isotopes as evidence for the age of weaning at the Angel site: a comparison of isotopic and demographic measures of weaning age. J Arch Sci 24:919-927

Sealy JC, Patrick MK, Morris AG, Adler D (1992) Diet and dental caries among Later Stone Age inhabitants of the Cape Province, South Africa. Am J Phys Anthropol 88:123-134

Smith CI, Nielsen-Marsh CM, Jans MME, Arthur P, Nord AG, Collins MJ (2002) The strange case of Apigliano: early "fossilization" of medieval bone in southern Italy. Archaeometry 44:405-415

Smith CI, Nielsen-Marsh CM, Jans MME, Collins MJ (2007) Bone diagenesis in the European Holocene I: patterns and mechanisms. J Arch Sci 34:1485-1493
Taylor RE, Ennis PJ, Slota PJ, Payen JR, Payen LA (1989) Non-agerelated variations in aspartic acid racemization in bone from a radiocarbon-dated late Holocene archaeological site. Radiocarbon 31:1048-1056

Tuross N (2002) Alterations in fossil collagen. Archaeometry 44:427-434 Tuross N, Fogel M, Hare PE (1988) Variability in the preservation of the isotopic composition of collagen from fossil bone. Geochim Cosmochim Acta 52:929-935

van Duin ACT, Collins MJ (1998) The effects of conformational constrains on aspartic acid racemization. Org Geochemy 29:1227-1232

van Klinken GJ (1999) Bone collagen quality indicators for paleodietary and radiocabon measurement. J Arch Sci 26:687-695 